\title{
Calcium Biofortification of Crops-Challenges and Projected Benefits
}

\author{
Marija Knez ${ }^{1,2 *}$ and James C. R. Stangoulis ${ }^{1}$ \\ ${ }^{1}$ College of Science and Engineering, Flinders University, Adelaide, SA, Australia, ${ }^{2}$ Centre of Research Excellence in Nutrition \\ and Metabolism, National Institute for Medical Research, University of Belgrade, Belgrade, Serbia
}

Despite Calcium (Ca) being an essential nutrient for humans, deficiency of $\mathrm{Ca}$ is becoming an ensuing public health problem worldwide. Breeding staple crops with higher Ca concentrations is a sustainable long-term strategy for alleviating Ca deficiency, and particular criteria for a successful breeding initiative need to be in place. This paper discusses current challenges and projected benefits of Ca-biofortified crops. The most important features of Ca nutrition in plants are presented along with explicit recommendations for additional exploration of this important issue. In order for Ca-

OPEN ACCESS

Edited by:

Jan Kofod Schjoerring,

University of Copenhagen, Denmark

Reviewed by:

Martin Broadley,

University of Nottingham,

United Kingdom

Debjyoti Sen Gupta,

Indian Institute of Pulses Research

(ICAR), India

*Correspondence:

Marija Knez

marijaknez186@gmail.com

Specialty section:

This article was submitted to

Plant Nutrition,

a section of the journal

Frontiers in Plant Science

Received: 17 February 2021

Accepted: 14 June 2021

Published: 16 July 2021

Citation:

Knez M and Stangoulis JCR (2021) Calcium Biofortification

of Crops-Challenges and Projected Benefits. Front. Plant Sci. 12:669053.

doi: $10.3389 / \mathrm{fp} / \mathrm{s} .2021 .669053$ biofortified crops to be successfully developed, tested, and effectively implemented in most vulnerable populations, further research is required.

Keywords: calcium, Ca biofortification, Ca deficiency, Ca in crop plants, Ca bioaccessibility

\section{CALCIUM-AN ESSENTIAL NUTRIENT FOR HUMANS}

Calcium (Ca) is the fifth most abundant inorganic element and accounts for about $2 \%$ of the total human body weight, and it is a vital nutrient for human health (Nordin, 1997). About $99 \%$ of $\mathrm{Ca}$ in the body is stored in the skeleton and the rest in the teeth and soft tissues, mostly as $\mathrm{Ca}$ phosphate (Nordin, 1997; Guo et al., 2014). The plasma level of total Ca is $2.2-2.6 \mathrm{mmol}$, while the amount of ionized $\mathrm{Ca}$ (i.e., $\mathrm{Ca}^{2+}$ ), which determines its biological potency, fluctuates between 1.1 and $1.4 \mathrm{mmol}$ (Prasad and Shivay, 2020). Ca concentrations in plasma are regulated by vitamin D, calcitonin, and thyroid hormone (Prasad and Shivay, 2020).

Calcium is a cationic macronutrient and a structural component involved in a variety of biological and physiological processes in the human body. It plays a crucial role in the structure and signaling development of bones and teeth (Sharma et al., 2017). Some of the fundamental regulatory functions in the human body involve Ca, i.e., hormonal secretion, coagulation of blood, initiation of enzymatic reactions, vascular vasodilation, muscle function, nerve impulse transmissions, cell proliferation, and intracellular metabolism (Pravina et al., 2013). Ca is a critical element for the development of peak bone mass in adolescents and young adults and the retention of bone mass in older adults (Balk et al., 2017). Besides, Ca has a protective role against various types of cancers, i.e., colorectal, ovarian, breast cancer (Gao et al., 2005; Lin et al., 2007), and it reduces the risk of developing insulin resistance and cardiovascular diseases (Parikh and Yanovski, 2003).

Higher dietary $\mathrm{Ca}$ intake is associated with lower blood pressure, lower body weight, reduced adiposity, and a decreased risk of developing hypertension (McCarron, 1989; Parikh and Yanovski, 2003). 
The recommended dietary intake of $\mathrm{Ca}$ is in the range of 800$1,300 \mathrm{mg} /$ day for adults and 1,300 mg/day for children above 9 years of age [The Food and Agriculture Organization (FAO) United Nations, 2002].

Calcium requirements must be met via diet; nonetheless, dietary consumption of $\mathrm{Ca}$ in humans is very often lower than recommended (Kranz et al., 2007; Balk et al., 2017). According to the most recent systematic review of dietary $\mathrm{Ca}$ intake among adults across 74 countries, the average national intake of $\mathrm{Ca}$ was in the range of 175-1,233 mg/day (Balk et al., 2017). Ca intakes below $500 \mathrm{mg} /$ day were reported for an adult population in Asia, while African and South American adults had Ca intake between 400 and $700 \mathrm{mg} /$ day. Only people living in Northern European countries had Ca intakes above 1,000 mg/day (Balk et al., 2017). The majority of adolescent girls (90\%) and boys (50\%) in the United States have a suboptimal dietary intake of Ca, and the situation is even more alarming in developing countries (Vatanparast et al., 2010).

Calcium deficiency is most prevalent in low- and middleincome countries where access to Ca-rich foods is limited. Kenya, Bangladesh, South Africa, India, Indonesia, Vietnam, South Korea, and China are currently the most affected regions, with $\mathrm{Ca}$ intakes between 25 and 33\% of recommended levels (Bromage et al., 2016; Dewey, 2016; Balk et al., 2017). More than $80 \%$ of the older adult population of South Korea has a Ca intake below the suggested values (Balk et al., 2017).

In 2011, Ca supply on a global scale was $684 \pm 211 \mathrm{mg} / \mathrm{capita} /$ day with estimated 3.5 billion people $(51 \pm 32 \%)$ worldwide suffering from $\mathrm{Ca}$ deficiency due to insufficient dietary intake (Kumssa et al., 2015). People living in countries with lower purchasing power have been shown to have a higher Ca deficiency risk. Based on the global food supply data, the mean Ca deficiency risk was $80 \pm 31$ for Africa, $29 \pm 27$ for America, $57 \pm 36$ for Asia, $11 \pm 7$ for Europe, and $11 \pm 4 \%$ for Oceania (Kumssa et al., 2015). Ca intake levels for over half of the countries worldwide are still unknown, which implies that the number of people affected by dietary Ca deficiency may be even larger than currently reported.

The consumption of staple foods with a limited Ca content and bioavailability is the major contributor to $\mathrm{Ca}$ insufficiency. Additionally, due to resource constraints, people living in developing communities, are not always able to pay for livestock or may only raise calves for complementing the income without consuming milk and milk products (Vatanparast et al., 2010). In developed countries where access to a variety of foods is not an issue, Ca deficiency mainly occurs as a consequence of avoidance and/or low intake of dairy products. Due to undesirable effects of lactose intolerance, a lot of people have limited consumption of the greatest dietary sources of $\mathrm{Ca}$, milk, and dairy products. About $65 \%$ of the population of the world is lactose intolerant; hence, they cannot count on dairy products for their Ca requirements (Puranik, 2017). Consequently, a significant number of people, including vegetarians and vegans, require alternative food sources to meet their Ca needs.

Inadequate dietary intake of $\mathrm{Ca}$ in humans has been associated with various diseases, i.e., rickets in children and osteopenia and osteoporosis in adults (Chan et al., 2007; Pettifor et al., 2018). Poor intake of $\mathrm{Ca}$ and $\mathrm{Ca}$ deficiency has numerous health and economic consequences (Kranz et al., 2007). The World Health Organization (WHO) has acknowledged osteoporosis as the ensuing public healthcare concern globally, affecting nearly 75 million people in Europe, the United States of America, and Japan (Haldipur, 2003). The worldwide cost of handling osteoporosis is estimated to be $\$ 131.5$ billion USD by 2050 (Lindsay et al., 2001).

Calcium deficiency in humans can be treated by increasing dietary $\mathrm{Ca}$ intake and absorption. Diversification of diets, food fortification, supplementation, and crop biofortification are strategies that could help alleviate $\mathrm{Ca}$ malnutrition (Puranik et al., 2017). While effective, both food fortification and supplementation have some drawbacks, the major being the inability to be easily accepted and applied by people in developing countries, and require ongoing infrastructure and investment. Alternatively, more cost-effective solutions with long-term benefits should be pursued.

In general, $50-70 \%$ of dietary Ca supply is from animal products, with fruits and vegetables contributing $10-40 \%$ of dietary $\mathrm{Ca}$ intake while cereals provide very little $\mathrm{Ca}$ (Welch and Graham, 1999; Khush, 2001). In order for people to absorb the recommended daily amounts of $\mathrm{Ca}$, they need to consume $\mathrm{Ca}$-rich foods with easily absorbable types of $\mathrm{Ca}$. Despite being the richest sources of dietary $\mathrm{Ca}$, the availability and the consumption of milk and dairy products are inadequate for different reasons, i.e., lactose intolerance or limited access to dairy foods. In addition, absorption of the available Ca from milk and dairy products is often limited because of the $\mathrm{Ca}-\mathrm{Mg}$ competition for absorption (Bennett and Sammartano, 2005). Plant-based foods provide $\mathrm{Ca}$ that is much more easily absorbed (Lanham-New, 2006).

Half of the population of the world depends on cereals as a basic food source (FAO et al., 2020). Fifteen crop plants are covering $90 \%$ of the total food energy intake worldwide. Major food crops are important to millions of people in developing countries, with three of them (i.e., rice, maize, and wheat) providing $60 \%$ of the food energy intake of the world (FAO et al., 2020). Staple crop self-sufficiency becomes a central element of national agricultural policies (FAO et al., 2020); thus, the production and application of Ca-biofortified staple crops could be a potential long-standing solution for alleviation of the $\mathrm{Ca}$ malnutrition problem worldwide.

\section{CALCIUM IN EDIBLE CROPS}

Plant-based products are the largest potential sources of more readily available and absorbable forms of $\mathrm{Ca}$ (Weaver et al., 1999; Lanham-New, 2006). The concentration of Ca in plant-based foods shows an extensive range of variation (Lanham-New, 2006). Two conditions must be met to classify a food as a good source of Ca. A typical serving size must comprise of at least $30 \mathrm{mg}$ of absorbable $\mathrm{Ca}$, and $100 \mathrm{kcal}$ of food must deliver $30 \mathrm{mg}$ of absorbable $\mathrm{Ca}$ (Fleming and Heimbach, 1994). In addition, diets should provide $200 \mathrm{mg} / 100 \mathrm{~g}$ of $\mathrm{Ca}$ to neutralize the negative impact of phytic 
acid (McCance and Widdowson, 1942). Processed flour should contain 235-390 mg/100 g of Ca, with an exclusion of wholemeal flour where the $\mathrm{Ca}$ content of $200 \mathrm{mg} / 100 \mathrm{~g}$ is considered acceptable (Broadley and White, 2010).

The lowest $\mathrm{Ca}$ content is found in fruit (i.e., apples and tomatoes) and tubers (potatoes), averaging $10 \mathrm{mg}$ of Ca per $100 \mathrm{~g}$. Much higher values are seen in green leafy vegetables (i.e., endive and spinach), with approximately $78 \mathrm{mg} / 100 \mathrm{~g}$ (Martínez-Ballesta et al., 2010). Similarly, bok choy and broccoli are good sources of Ca (Yang et al., 2012). Certain foods like ivy gourd (Coccinia grandis), kale (Brassica oleracea), and Chinese mustard greens (Brassica juncea) have comparable Ca content and absorbability to dairy products (Dayod et al., 2010).

Cereals are major food sources for people in developing countries, and, as such, the largest potential sources of easily available Ca. Similarly, cereals and cereal-based products contribute substantially to the dietary intake of total $\mathrm{Ca}$ in developed country populations. Around $37 \%$ of the total $\mathrm{Ca}$ intake of men and women living in Greece was coming from cereals (Welch et al., 2009).

Likewise, $28 \%$ of dietary $\mathrm{Ca}$ intake of people in United Kingdom was drawn from cereals and cereal-based products; $28 \%$ of the dietary intake of Ca in females and $32 \%$ of the $\mathrm{Ca}$ intake of males are based on cereal sources (Broadley and White, 2010). Therefore, potential increases of Ca bioaccessibility in cereal crops could provide notable benefits, both to developing and developed country populations.

Major staple food grains (i.e., rice, wheat, and maize) that make up the central part of diets within both developing and industrialized countries are relatively poor sources of Ca (Jeong and Guerinot, 2008). Ca content of major crop plants is presented in Figure 1. The exception to the rule of relatively low $\mathrm{Ca}$ content of cereals is finger millet (Eleusine coracana), a crop cultivated in Eastern and Central Africa and India that contains three times more Ca than milk, $344 \mathrm{mg} / 100 \mathrm{~g}$ (Seetharam, 2001). $\mathrm{Ca}$ concentration in 36 genotypes of finger millet varied from 162 to $489 \mathrm{mg} / 100 \mathrm{~g}$ with a mean value of $320 \mathrm{mg} / 100 \mathrm{~g}$ grain (Upadhyaya et al., 2011; Sharma et al., 2017). Whiteseeded finger millet had much higher $\mathrm{Ca}$ concentration when compared with the brown-seeded varieties; $330 \mathrm{mg} / 100 \mathrm{~g}$ as opposed to $296 \mathrm{mg} / 100$-g grain (Seetharam, 2001). As such, finger millet has enormous potential as a nutritional security crop due to the unusually high Ca concentration (Sharma et al., 2017). Furthermore, millets are often resistant to pests and diseases, and are drought-tolerant crops, however, the major downside of finger millet is the predominance of antinutritional factors that reduce Ca bioavailability (Vinoth and Ravindhran, 2017). Besides being a great source of $\mathrm{Ca}$, this crop has the potential to be used as a model to examine the mechanisms that contribute to high $\mathrm{Ca}$ concentration in grains.

The green revolution-stimulated research on staple foods and the lower-yielding cereals and legumes have been replaced with higher-yielding varieties that are generally poorer sources of essential nutrients, including Ca (Graham et al., 2007). The consumption of $100 \mathrm{~g}$ of a cereal (i.e., wheat) provides an intake of $40-50 \mathrm{mg}$ of $\mathrm{Ca}$, which is equivalent to $5-6 \%$ of the recommended daily requirements (Sanwalka et al., 2011). One processed serving portion of finger millet provides $0.2 \mathrm{~g} \mathrm{Ca}$, which is $25 \%$ of the recommended intake of $\mathrm{Ca}$ for children and adolescents (Sanwalka et al., 2011; Ekbote et al., 2017).

In summary, staple crops that could provide sufficient amounts of $\mathrm{Ca}$, predominantly to people of low-income groups, are required. These populations are usually dependent on the foods they produce for meeting their $\mathrm{Ca}$ needs, so $\mathrm{Ca}$ rich, traditional, and locally well-adapted crops are desired. Regular consumption of finger millet has a great potential to control the occurrence of Ca deficiency. Similarly, the action toward increasing the potential of other major crops to become promising food sources of Ca should be stimulated. Finally, the development and application of Ca-biofortified staple crops should be considered as an approach to improving dietary $\mathrm{Ca}$ intake of the most vulnerable populations.

\section{CALCIUM IN PLANTS}

Comprehensive explanations of the role of $\mathrm{Ca}$ in plants, $\mathrm{Ca}$ transport mechanisms, Ca transporters in cellular membranes, $\mathrm{Ca}$ channels and signaling, $\mathrm{Ca}$ binding proteins, and phylogeny of shoot $\mathrm{Ca}$ concentrations within the plant tissues are offered elsewhere (White, 2001; White and Broadley, 2003, 2005; Mohiyuddin et al., 2010); therefore, only the most important aspects are covered here very briefly.

Plants require relatively large amounts of $\mathrm{Ca}$, typically from 0.1 to $4.4 \%$ dry matter (Broadley et al., 2003). Still, Ca deficiency in plants/field-grown crops is generally rare, but it could be seen in the plants grown in the soils with high levels of acidic depositions or low-based saturation and in the leaching prone soils (McLaughlin and Wimmer, 1999). Ca deficiencies can occur on highly exposed tropical soils, on sodic and saline soils, when $\mathrm{Ca}$ is reduced in the presence of other cations, i.e., $\mathrm{Na}$ or $\mathrm{Al}$ (Broadley and White, 2010). Deficiency of Ca in crops also arises when the $\mathrm{Ca}$ is temporarily inaccessible to the growing tissues (Ho and White, 2005). Plants can suffer from Ca toxicity if excessive amounts of $\mathrm{Ca}$ are present in a rhizosphere solution; the abundance of $\mathrm{Ca}$ oxalate crystals in the cell walls increases with high Ca fertilization and under conditions of high humidity (White and Broadley, 2003). Most of the Ca-based components found in the soils are insoluble and consequently unavailable to plants, as $\mathrm{Ca}$ is taken from the soil solution in the form of $\mathrm{Ca}^{2+}$.

The mass flow of water transports $\mathrm{Ca}$ toward the root and once in the root/the cell wall space, $\mathrm{Ca}^{2+}$ either binds to negatively charged residues within the Donnan-free space or to membranes. Furthermore, $\mathrm{Ca}$ is transported across the cell plasma membrane down the electrochemical gradient for $\mathrm{Ca}^{2+}$ and is simplistically delivered to the xylem (White and Broadley, 2003). Ca is transported via the apoplastic pathway to the xylem (White, 2001), while a symplastic pathway permits the cells to control the rate of $\mathrm{Ca}$ transport to the shoot by the plasma membrane $\mathrm{Ca}^{2+}$-ATPases or $\mathrm{Ca}^{2+} / \mathrm{H}^{+}$antiporters of the cells within the stele (White, 2001). Ca is immobile in the phloem, so tissues that do not transpire easily (i.e., fruits, seeds, and tubers) have low Ca concentrations due to low transpiration rates in these tissues (White and Broadley, 2003; Karley and White, 2009). 


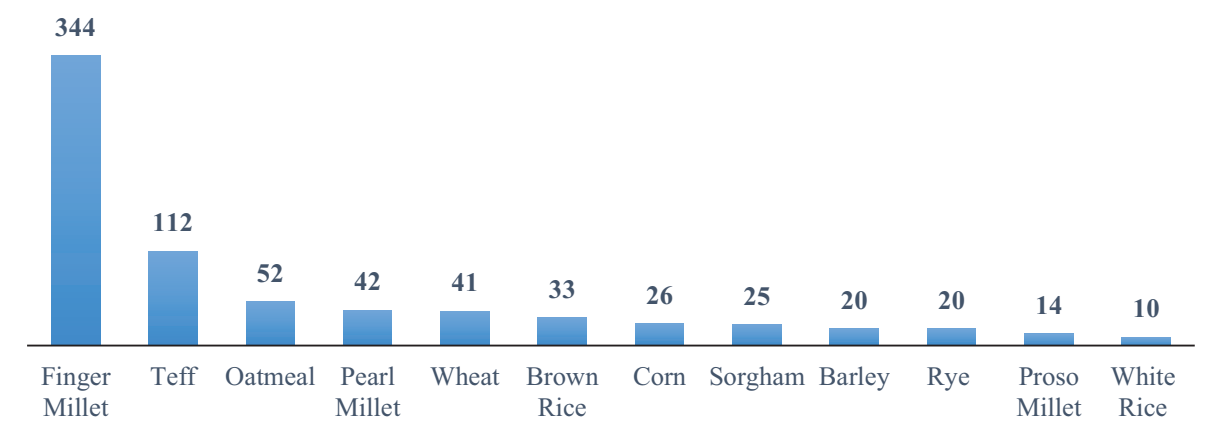

FIGURE 1 | Ca content of different crops (mg/100 g edible portion). Based on data provided by McKevith (2004), Saleh et al. (2013), and Shobana et al. (2013).

Once in the plant cells, $\mathrm{Ca}$ is relatively immobile and is not easily circulated to growing parts of the plants, which can lead to local deficiencies, despite the adequate supply of Ca. This causes many side effects, local plant cell necrosis, reduced plant ability to cope with abiotic and biotic stress, decreased crop quality, and reduced yield (White and Broadley, 2003; Dayod et al., 2010).

Calcium is differentially distributed within different cell types but also intracellularly, with organelles, i.e., vacuoles, mitochondrion and an endoplasmic reticulum, having a higher Ca concentration than the cytosol (Dayod et al., 2010). The exchange capacity of the cell wall for $\mathrm{Ca}$ depends on the tissue type and environmental conditions (Fritz, 2007); however, the soluble $\mathrm{Ca}$ is generally located in specific cells of the shoot (Karley et al., 2000). For example, in cereals, total $\mathrm{Ca}$ is lowest in the mesophyll and highest within the epidermal leaf vacuoles (Karley et al., 2000).

Several techniques have been suggested for increasing Ca uptake by plants. One of the ways to accomplish this is by increasing the mass flow of water and $\mathrm{Ca}$ to the roots, a process often limited by a low supply of water in developing countries (White, 2001; Puranik et al., 2017). An alternative method is to increase the binding of $\mathrm{Ca}$ to cell walls or improve the entry of $\mathrm{Ca}$ into the cell walls by increasing the activity of Ca-permeable transporters (White, 2001). In this context, increasing the cationexchange capacity (CEC) of the cell walls is a strategy that could bring more Ca into plants (Fritz, 2007). CEC of cereals is low, which could explain their low-Ca content. Ca concentrations in plant shoots increase several folds in plants exposed to Ca-rich habitats without negative effects on plant growth (Jefferies and Willis, 1964). While this sounds like a promising strategy, the undesirable effects of this approach are still not known as Casignaling pathways are not entirely understood, and the proposed overstimulation could disturb tightly regulated transport of $\mathrm{Ca}$ within plant cells (Dodd et al., 2010; Yang et al., 2012). The Ca accumulation in plants is regulated by active tonoplast processes (Conn and Gilliham, 2010).

The largest potential storage compartment in the plant is the vacuolar lumen, so it is usually chosen for increasing plant Ca storage capacity, with CA (Ca-ATPase) and ACA (autoinhibitory Ca ATPase) being the most important proteins for Ca accumulation into the vacuoles (Leigh and Sanders, 1997; Conn and Gilliham, 2010).
There are several approaches to increasing the $\mathrm{Ca}$ concentration and bioavailability of staple food crops, and they include the following: increasing $\mathrm{Ca}$ supply to cells; improving the Ca uptake by cells; removing the antinutrients (compounds that make $\mathrm{Ca}$ inaccessible); and increasing $\mathrm{Ca}$ storage at the cellular and tissue level (Yang et al., 2012; Puranik et al., 2017).

The presented findings indicate that strategies for improving $\mathrm{Ca}$ uptake and storage of crop plants exist, but most of these mechanisms are not completely developed and require further research.

All available methods for increasing Ca uptake and storage of plants require careful consideration of potential side effects.

\section{THE INTERACTION OF CALCIUM WITH OTHER NUTRIENTS}

The interaction of $\mathrm{Ca}$ with other nutrients and potential antagonistic or synergistic effects of their interplay are currently poorly understood. The ability of $\mathrm{Ca}$ to bind phytate and consequently improve the absorption of other major minerals, i.e., $\mathrm{Zn}, \mathrm{Fe}$, or vice versa is still inconclusive.

Multiple nutrient germplasm data have recently been evaluated for pearl millet, demonstrating that out of the 10 high-Fe accessions, only one accession had more than $58 \mathrm{mg} / \mathrm{kg}$ $\mathrm{Zn}$, and four accessions were with higher-Ca content, 201$235 \mathrm{mg} / \mathrm{kg}$ (the lowest content measured was $161 \mathrm{mg} / \mathrm{kg}$ ) (Govindaraj et al., 2020). Ca content of pearl millet grains had a positive association with concentrations of $\mathrm{Fe}, \mathrm{Zn}$, and many other examined nutrients, but significant associations were only evident for Fe and Mn (Govindaraj et al., 2020). Lentil seed $\mathrm{Ca}$ concentrations are directly correlated with $\mathrm{Mg}$ and $\mathrm{Zn}$ concentrations but negatively with Fe (Toklu et al., 2017). Strong positive correlations were seen for $\mathrm{Ca}$ in Arabidopsis thaliana, where $\mathrm{Ca}$ correlated with $\mathrm{Mg}, \mathrm{Mn}, \mathrm{P}$, and $\mathrm{Fe}$ (Vreugdenhil et al., 2004). An examination of the element-binding affinities of numerous elements to phytate at $\mathrm{pH} 7$ demonstrates that Ca-binding constants are much lower compared with binding capacities of other elements $(\mathrm{Cu}>\mathrm{Zn}>\mathrm{Mn}>\mathrm{Fe}>\mathrm{Ca})$, signifying that a better release of $\mathrm{Ca}$ through the gastrointestinal tract can occur (Torres et al., 2005). 
Calcium has a significant protecting role against $\mathrm{Cd}$ toxicity in plants (Huang et al., 2017) as Ca controls Cd uptake and translocation in a plant species in a dose-dependent manner (Gong et al., 2016). Lower doses of Ca promote Cd uptake and translocation in plants, but higher doses reduce the $\mathrm{Cd}$ uptake in the roots (Eller and Brix, 2015). The accumulation of $\mathrm{Cd}$ in plants was significantly reduced with increasing $\mathrm{Ca}$ concentrations in rice plants; $\mathrm{Ca}$ diminished root $\mathrm{Cd}$ uptake and stimulated translocation of $\mathrm{Cd}$ from roots to shoots (Zhang et al., 2020a).

The potential impact of modifications in Ca intake on dietary Fe bioavailability showed that both heam and non-heam $\mathrm{Fe}$ absorption were inhibited by dairy products and Ca supplements (Hallberg et al., 1992; Thompson et al., 2010). The inhibitory effect of $\mathrm{Ca}$ on $\mathrm{Fe}$ absorption is most pronounced in small, simple meals but is less noticeable when larger complex meals are consumed, most likely because of the combined effect of all modifiers of Fe absorption in a composite meal (Fairweather-Tait and Hurrell, 2007). However, Ca supplementation has a negative effect on Fe absorption only if the habitual $\mathrm{Ca}$ consumption is very low; otherwise, the influence is not significant (Lynch, 2000).

The inconsistent findings on the influence of higher $\mathrm{Ca}$ concentrations on the absorption of major micronutrients shows that complex nutrient interactions exist, suggesting further research is needed to clarify the effect of Ca on the availability and absorption of other important toxic and non-toxic elements. A better understanding of the mechanistic interactions of a number of microminerals within the crop plants tissues is needed. The optimal conditions for stimulating the desired interactions, i.e., soil properties, climate, Ca concentrations, need to be determined to produce Ca-biofortified crop varieties with the most desirable traits. The micronutrient interactions at the human gut level should also be taken into account.

\section{ANTINUTRIENTS AND BIOAVAILABILITY}

Calcium bioavailability depends on both the food source and the presence of anti-nutritional factors. The presence of antinutrients can bind elemental nutrients and prevent absorption in the gut. In plants, $\mathrm{Ca}$ is complexed with phytate, fiber, polyphenols, proteins, fatty acid, lactate, and oxalate (Krishnan et al., 2012; Yang et al., 2012). The formation of Ca-oxalate crystals makes $\mathrm{Ca}$ completely inaccessible for uptake and absorption along the length of the gut, so oxalate is referred to as a strong "antinutrient" (Heaney and Weaver, 1989). Plant species deposit Ca-oxalate crystals in their vacuoles or they hold soluble oxalate in the form of sodium and potassium salts. Due to the complexation of $\mathrm{Ca}$ with oxalate, $\mathrm{Ca}$ is indigestible from the many edible plants high in Ca (Morris et al., 2007).

Phytic acid, known as "phytate" or "inositol hexakisphosphate" (IP6) is another major antinutrient of $\mathrm{Ca}$ in plants. Phytate chelates $\mathrm{Ca}$ and makes complexes that humans cannot digest. High concentrations of phytate in plants can cause Ca deficiency and malnourishment, even if the concentration of $\mathrm{Ca}$ within the edible part of the plant is adequate. Unrefined cereals and legumes contain the highest concentrations of phytate $(600 \mathrm{mg} / 100 \mathrm{~g}$ of dry weight) (Lott et al., 2009). Dephytinisation can enhance the amount of absorbable $\mathrm{Ca}$ in plants, but not to a point to overcome the deficits of low-Ca content of plant-based foods used in developing countries (Gibson et al., 2010).

Phytate to $\mathrm{Ca}$ molar ratios are used to predict $\mathrm{Ca}$ bioavailability; the phytate:Camolar ratio above 0.24 is shown to impair Ca absorption (Morris and Ellis, 1989). Food processing approaches, such as germination, fermentation, and thermal treatments, are generally seen as promising tools for increasing Ca bioavailability, as they tend to reduce the amounts of phytate and improve Ca bioaccessibility (Zhang et al., 2020b).

Phytase, an enzyme that catalyzes the hydrolysis of phytic acid into inositol phosphate intermediates, could be present within germination seeds or formed throughout the microbial activity, and thus phytases are the main determining factors of Ca bioavailability (Zhang et al., 2020c). Ca bound to indigestible food components could pass to the colon and might turn out to be absorbable through enzymatic reactions of microbiota (Weaver et al., 1999). For example, probiotics, containing bifidobacterium, lactobacillus, and bacteroids increased Ca balance in the gut and contributed to improvements in bone mineral content (ScholzAhrens, 2016). The Ca content in the bones of animals improved when lactobacillus paracasei. L. plantarum or bifidobacterium longum was supplied to rats (Parvaneh et al., 2015). Probiotics increase absorption of $\mathrm{Ca}$ by producing SCFAs that improve Ca release and absorption (Asemi and Esmaillzadeh, 2013). SCFAs, such as acetate, butyrate, and propionate, enhance $\mathrm{Ca}$ solubility and increase the expression of $\mathrm{Ca}$ transporters (Skibsted, 2016). The bioavailability of $\mathrm{Ca}$ in certain plants could be higher than anticipated, and it requires to be adequately assessed. For example, $\mathrm{Ca}$ in Chinese cabbage is found to be 1.3 times higher bioavailability than milk Ca (Kamchan et al., 2004).

Phytase treatment of beans improved the amount of absorbable Ca by a third (Weaver et al., 1993). Reduction of phytic acid in soybean seeds of 70\% increased Ca bioaccessibility by around 33\% (Heaney et al., 1991). High Ca bioavailability was measured in Brassica vegetables that are known as phytate and oxalate free vegetables (Lucarini et al., 1999). Chickpea genotypes with lower levels of phytic acid and phenolics had increased Ca bioavailability, regardless of their Ca concentrations in the seeds (Sharma et al., 1996). Chickpea is a seed with a relatively low phytate content and a good source of mineral elements, including $\mathrm{Ca}$, so this plant could be a favorable candidate for increased concentrations of $\mathrm{Ca}$ in breeding programs (Dragicevic et al., 2018). However, the concentration of phytate alone is not always responsible for inhibited $\mathrm{Ca}$ bioavailability, while a synergistic role of protein and phytate seems to have a fundamental role in the context of $\mathrm{Ca}$ bioavailability. Similarly, the Ca:phytate molar ratio is not the best predictor of $\mathrm{Ca}$ bioavailability, as phytate is modified by other food ligands, proteins, and other interacting cations (Zhang et al., 2020b).

Low-phytic acid (lpa) crops could genetically be produced, but phytic acid contains certain health-promoting properties for 
both plants and humans, so simply removing the phytate may not provide the desired long-term outcomes (Bowen et al., 2007). Phytates play a major role in plant metabolism, growth, and resistance to biotic and abiotic stresses (Singh et al., 2017). Phytic acid is the main phosphorous store for the seeds and is often linked to adverse effects on the plant (Singh and Raghuvanshi, 2012). In humans, phytate has a protective role against various chronic diseases (Kumar et al., 2016).

However, it is important to note that certain perturbations in phytic acid synthesis may beneficially affect the distribution of minerals within the cereal grain tissues and result in higher mineral levels in the endosperm (Cichy and Raboy, 2009). Dietary phytate certainly has beneficial roles in human health but may not always be to the degree as it is often claimed (Raboy, 2020). Besides, the benefits of low phytate foods should not be ignored and neglected (Raboy, 2020), and breeding for elevated levels of $\mathrm{Ca}$ may not be effective if phytic acid levels remain high (Raboy, 2020). For example, phytate levels in the various grain seeds are not well correlated with $\mathrm{Fe}$ and $\mathrm{Zn}$ levels; however, animal and human studies describe that low-phytate grains may result in enhanced absorption of minerals (Raboy, 2020). A combination of low phytate with a high mineral approach may provide a more suitable solution for improving the long-term global bioavailability of $\mathrm{Ca}$ in staple crops and for improving Ca nutrition of most vulnerable population groups, an idea that requires further consideration.

The previously discussed strategies have the potential to increase the content, accumulation, and bioavailability of $\mathrm{Ca}$ in target crops, but most of these procedures are expensive and they can hardly be applicable to be applied by developing countries. The biofortification approaches that enhance $\mathrm{Ca}$ concentration and $\mathrm{Ca}$ bioavailability of staple crops are more likely to be adopted in low-income societies and to bring the desired outcomes. Successful biofortification of crops with $\mathrm{Ca}$ requires a comprehensive understanding of the physiological and genetic basis of $\mathrm{Ca}$ accumulation in staple foods. Further work is needed in order to produce crop plants with higher Ca content without negatively affecting plant functioning and yield. Techniques that regulate $\mathrm{Ca}$ transport and storage in plants are still not entirely understood, so further research of potential mechanisms that control the transport and storage of $\mathrm{Ca}$ in plants is necessary. The role of molecular breeding, genomics, and transgenic approaches should be explored to understand the mechanisms of $\mathrm{Ca}$ accumulation in selected staples. Identification of potential candidate genes and controlling elements needed for elevated $\mathrm{Ca}$ accumulation in the grains is required. Genetic engineering and various imaging approaches could be used for studying the distribution of $\mathrm{Ca}$ and changes in the chemical forms of $\mathrm{Ca}$ in the plant cells.

The manipulation of the expression and activity of particular Ca transporters within the plants could lead to increased supply, uptake, and accumulation of $\mathrm{Ca}$ within crop plants, but this requires additional investigation. The reduction of antinutrients during plant growth and development is a strategy for increasing bioavailability from Ca-rich crops. The production of low phytate and high $\mathrm{Ca}$ staples may provide the best suitable solution; however, their application should be approached with caution to avoid the potentially negative effects of low phytate on the health status of both plants and humans.

\section{THE EFFECT OF PROCESSING AND COOKING PROCEDURES ON THE CALCIUM CONTENT}

The food preparation and processing techniques affect the total $\mathrm{Ca}$ content and Ca bioavailability of crop grains. Decortication (removal of the seed coat matter) of finger millet lowered $\mathrm{Ca}$ content but increased the bioaccessibility of Ca by $15 \mathrm{~g} / 100 \mathrm{~g}$ (Krishnan et al., 2012). The seed coat of finger millet grains contains $40 \mathrm{~g} / 100 \mathrm{~g}$ of total $\mathrm{Ca}$, so its removal reduces total $\mathrm{Ca}$ content to a degree (Krishnan et al., 2012).

Cereal grains are naturally low in Ca concentration, with the husk and brain, containing the highest concentrations of $\mathrm{Ca}$, very often removed during milling procedures (Broadley and White, 2010). However, parboiling before milling may be a useful strategy for increasing the $\mathrm{Ca}$ content in the endosperm, as, during the process, $\mathrm{Ca}$ from its natural place of residence in the bran and aleurone layer moves to the endosperm (Oli et al., 2016). Autoclaving causes a considerable reduction of Ca concentration in lentils (Hefnawy, 2011).

Sonication has been shown to notably increase the Ca content of apple juice (Abid et al., 2014). No significant differences in $\mathrm{Ca}$ content were seen between the fresh and frozen products while certain reductions in $\mathrm{Ca}$ levels were observed during prolonged storage periods of fruits and vegetables, most likely caused by a moisture loss (Bouzari et al., 2015).

Milling and conversion of grains into other food products cause hydrolysis of IP6 to lower inositol phosphates (IP5IP1) and produce products with enhanced bioaccessibility of Ca. Short-term high-temperature treatment of finger millet grains had no negative effect on Ca content but lowered Ca bioaccessibility by 19\% (Krishnan et al., 2012). Similarly, microwave cooking by boiling did not improve Ca bioavailability (Amalraj and Pius, 2015). Popping the native millet for the production of a product named "Hurihittu," slightly decreased the bioaccessibility of $\mathrm{Ca}$ by $7 \mathrm{~g} / 100 \mathrm{~g}$ without affecting the phytic acid content (Krishnan et al., 2012).

Malting of millet decreased the total Ca content by $20 \mathrm{~g} / 100 \mathrm{~g}$, reduced the content of antinutrients (phytate, $84 \mathrm{~g} / 100 \mathrm{~g}$; dietary fiber, $81 \mathrm{~g} / 100 \mathrm{~g}$ ) and consequently significantly improved the bioaccessibility of Ca, $68 \mathrm{~g} / 100 \mathrm{~g}$ (Krishnan et al., 2012).

Similar to malting, the germination process lowered $\mathrm{Ca}$ content, reduced phytic acid, and increased the bioaccessibility of Ca (Platel et al., 2010; Krishnan et al., 2012). Germination reduced the Ca:phytate and Ca:oxalate molar ratios in flaxseeds and increased bioaccessibility of $\mathrm{Ca}$ was observed with an in vitro gastrointestinal digestion process; however, there were no increases in $\mathrm{Ca}$ absorption in the animals (Vinco Pimenta et al., 2020).

Sprouting has been shown to reduce the phytate levels and improve the extractability of Ca (Mbithi-Mwikya et al., 2000). Whole grain finger millet flour had a much higher $\mathrm{Ca}$ content than the flour made from decorticated grains 
(Hemanalini et al., 1980). Furthermore, decortication improved Ca bioavailability (Hemanalini et al., 1980). In addition, the fermentation process improved $\mathrm{Ca}$ bioavailability by $20 \%$ and reduced the inhibitory activity of antinutrients, phytates primarily (Makokha et al., 2002).

Out of all processing procedures, milling, malting, and germination were the most efficient techniques for improving Ca bioaccessibility of finger millet, and this was primarily due to reduced concentration of antinutrients as a consequence of applied procedures. An increased phytate:Ca molar ratio decreased the bioaccessibility of $\mathrm{Ca}$, even when the molar ratio was below the estimated critical value of 0.24 (Krishnan et al., 2012; Ma et al., 2016).

Calcium fortification processes started to be employed in the Latin America region as early as 1,200-1,500 BC by the so-called "nixtamalization" process (Naila et al., 2019). Nixtamalization, the procedure of soaking and cooking cereals in a lime solution, has been shown to increase Ca content of grains and to improve Ca absorption (Arnaud et al., 2007; Naila et al., 2019). Naila et al. (2019) have recently demonstrated that the Ca content of rice can be improved by fortification of rice with different concentrations of quenched lime. Cooking rice grains in a lime solution significantly improved the Ca content (Naila et al., 2019). Similar findings were provided for corn grains when they were soaked and cooked in a lime solution before dehulling (Bressani, 1990). The Ca content of tortillas made from nixtamalized corn flour was increased by 22-38-fold compared with the Ca content of tortillas made from conventional corn flour (Rosado et al., 2005).

In addition, the absorption of $\mathrm{Ca}$ was enhanced (Rosado et al., 2005), which was most likely stimulated by reduced concentrations of antinutrients (i.e., phytate, oxalate, and dietary fiber) in soaked grains (Rosado et al., 2005; Naila et al., 2019).

Calcium carbonate and $\mathrm{Ca}$ chloride have also been used as nixtamalization agents, and experiments conducted on maize plants showed that treatment with these agents could lead to modifications in the digestibility of resistant and soluble starches (Roldan-Cruz et al., 2020). Cooking reduces the oxalate content of the food by discharging losses into the cooking water (Savage et al., 2000). Concentrations of Ca significantly decreased upon cooking sweet chestnuts (Gonçalves et al., 2012).

The soaking time was positively associated with the Ca content of corn grains (Palacios-Fonseca et al., 2009) and millet flour (Ocheme et al., 2010), while no such association was found for rice plants (Naila et al., 2019). Soaked grains produced flour with a lower content of proteins, phytic acid, trypsin, and tannin inhibitors (Ocheme et al., 2010), showing that soaking could diminish some antinutritional properties. Organoleptic properties of Ca-modified lettuce varieties were not changed, so this suggests that biofortification of crop plants with Ca does not affect taste and flavor (Morris et al., 2008).

A careful selection of appropriate processing methods is required to preserve the maximum bioaccessible amounts of total $\mathrm{Ca}$ in designated cereal grain products. Further research is needed to extrapolate the procedures with the most beneficial effects on Ca content and bioaccessibility and with a minimum negative impact of reduced antinutrients content both for plant development and human consumption. Processing methods with the most substantial positive outcomes on $\mathrm{Ca}$ bioaccessibility should be selected and promoted among consumers.

\section{ENVIRONMENTAL EFFECTS ON CALCIUM IN TARGET CROPS}

The influence of environmental conditions on the Ca content of cereal plants has not been investigated extensively. The limited available evidence points out that the highest concentrations of $\mathrm{Ca}$ in the grains of wheat plant seeds were obtained during the most humid year. The concentration of $\mathrm{Ca}$ in wheat grains varied by $40 \%$ between the dry- and humid-seasons-grown wheat grains (Gomez-Coronado et al., 2019). The effect of crop season on the Ca content of common beans showed that the mean $\mathrm{Ca}$ content in the dry crop season was 2.6 times higher compared with rainy crop-season-grown counterparts (Fernandes et al., 2016).

Climatic conditions are known to affect the concentrations of phytate in plants. Wider variability in phytate content is due to climatic rather than genotypic variations. However, inconsistent data are obtained; the lowest phytate levels were measured in the most humid year by some (Gomez-Coronado et al., 2019), while others have found the lowest concentrations in the driest year (Ficco et al., 2009). The yield was increased during the humid years, and a phytate:Ca ratio showed the highest values during the driest season (Gomez-Coronado et al., 2019). The relationship between the Ca content of crops and soil characteristics is affected by soil Ca content, mineral bioavailability, and plant function (Wood et al., 2018). Crop $\mathrm{Ca}$ concentration was directly associated with soil $\mathrm{pH}$, with higher mineral availability in plants grown on acidic soils (Fordyce, 2005). An increase in soil pH improves the relationship between the extractable soil $\mathrm{Ca}$ and crop $\mathrm{Ca}$ concentrations (Bevis and Hestrin, 2020).

The effect of root interaction with a particular soil type is another environmental factor that may influence the Ca sensing and transport mechanisms in a different way. Crops grown on calcareous soils had higher $\mathrm{Ca}$ content than the crops grown on non-calcareous soils (Joy et al., 2015). However, the characteristics of the soils do not seem to be the main drivers of heterogeneity in crop Ca concentrations. The relationship between the soil characteristics and the crop $\mathrm{Ca}$ concentrations mainly depends on the crop variety, climate, and agricultural practices, but additional research is needed to fully support this preliminary idea (Bevis and Hestrin, 2020).

Certain genotypes of crop plants have the potential to accumulate $\mathrm{Ca}$ under specific environmental conditions, and these genotypes should be used in breeding programs to produce biofortified grains and to help alleviate Ca deficiency in affected populations. The effect of various agronomic (vegetative growth, disease resistance, and stress resilience) and ecological (climate change) conditions on the Ca content of crops should be additionally examined. Mapping environmentally variable 
traits in a genetically highly diverse array of crop plants remains a challenge.

\section{ANALYSIS OF CALCIUM IN ENRICHED CROPS}

Calcium has multiple roles in plant cells; thus localization, abundance, and speciation vary among the $\mathrm{Ca}$ complexes involved in different processes. Furthermore, it is thought that Ca-enhanced foods have altered $\mathrm{Ca}$ distribution and speciation in the tissues.

Calcium distribution in edible crop plants is usually assessed, using inductively coupled plasma-optical emission spectrometry (ICP-OES), inductively coupled plasma-mass spectrometry (ICP$\mathrm{MS}$ ), atomic absorption spectrometry (AAS), synchrotron X-ray fluorescence (SXRF) or X-ray absorption spectroscopy (XAS), that display all of the forms of $\mathrm{Ca}$, regardless of their solubility (Yang et al., 2012). SXRF is particularly suitable for analysis of the membrane transport proteins, and it allows measurement of $\mathrm{Ca}$ in fresh, fully hydrated, or living tissue (Yang et al., 2012).

$\mathrm{X}$-ray fluorescence (XRF) is shown to be a reasonably highthroughput method for measuring $\mathrm{Ca}$ in plant tissues (Kalcsits, 2016). The correlation coefficient ranged from 0.73 to 0.97 in apple and pear fruit, between Ca measurements taken by XRF and Ca values determined via traditional laboratory analysis (Kalcsits, 2016). XRF can be employed as a rapid easily applicable analytical technology for the determination of minerals, including $\mathrm{Ca}$ (McCarthy et al., 2020). Similarly, XRF technology can be used to explore the efficacy of biofortification methods in improving $\mathrm{Ca}$ concentrations and distribution within the grains, and it could be employed for analyzing the interaction of $\mathrm{Ca}$ with antinutrients and for examining interactions among multiple elements (Zhang et al., 2017; Vigani et al., 2018).

$\mathrm{X}$-ray fluorescence is appropriate for examining the concentration and distribution of various elements within plant tissues (Guild et al., 2017; Feng et al., 2020). It allows for quick analysis of elements in the vegetation stages of plants. Handheld XRF is a portable device that allows a rapid assessment of Ca concentrations and variability on the surface and special distribution of $\mathrm{Ca}$ at the organ or plant level (Feng et al., 2020).

The benefits of using XRF techniques for the determination of Ca concentrations in crops are the following: it is a fast, high throughput method that can measure several elements in parallel, minimal sample preparation needed, no chemical reagents are needed, samples are not damaged, and there is no waste produced; the procedure does not change the chemical speciation and distribution of elements (Feng et al., 2020). Synchrotron XRF offers good sensitivity and excellent special resolution. Some downsides are that the long-term exposure to X-rays may damage the sample, and, sometimes, superimposed peaks occur due to interference with other elements (Feng et al., 2020).

The position of the grain affects the concentration of $\mathrm{Ca}$ within a crop plant, and this could have some important implications for plant breeding strategies. Ca concentration decreases as the distance from the rachis increases. The lowest $\mathrm{Ca}$ concentrations were found in distal grains that mainly contribute to grain yield while the wheat grains positioned more distally from the rachis contained 30\% lower concentrations of Ca (Calderini and Ortiz-Monasterio, 2003). The concentration of $\mathrm{Ca}$ declines through grain filling, so, in wheat plants, $\mathrm{Ca}$ concentrations on the first sampling date were $70 \%$ of their value at physiological maturity (Calderini and Ortiz-Monasterio, 2003). Higher concentrations of $\mathrm{Ca}$ are found in the bran and germ in raw rice while the endosperm has a low Ca content (Oli et al., 2016).

Understanding the link between the location of $\mathrm{Ca}$ in the plant cell and Ca bioavailability is important to be known so that molecular targets controlling $\mathrm{Ca}$ position in plants can be developed.

\section{ENRICHMENT OF STAPLE FOOD CROPS WITH CALCIUM}

Intervention programs that include nutrition education, fortification, and supplementation have been effective in alleviating various micronutrient deficiencies; however, they are expensive, entail persistent support, and very often fail to reach all individuals at risk (Graham et al., 2007). Several economic, political, and logistical challenges tend to be present and discourage the appropriate implementation of these strategies (Graham and Welch, 1995). The low-income countries lack robust food-processing infrastructure, and fortified products are usually unaffordable to the poor (Velu et al., 2014). In addition, the regulatory systems that could support the implementation of fortified foods in developing countries are frequently lacking (Graham and Welch, 1995). Ca supplements, while efficacious, will only be of use to informed, well-motivated, and educated consumers, and, as in every other form of supplementation, are less likely to be beneficial in disadvantaged areas (Yang et al., 2012).

Wheat and rice are the two most commonly consumed cereal crops worldwide (FAOSTAT, 2017). Around 765 million tons of wheat and 509 million tons of rice are produced per year (FAOSTAT, 2017). Rice is the main staple food for half of the population of the world (Juliano, 1990). Populations dependent on rice get $75 \%$ of their daily dietary energy through its consumption (FAOSTAT, 2017). Consequently, increasing Ca in edible grains has the potential to impact a large number of people. This can be achieved by several means, including fortification (adding a nutrient to the grain), biofortification (utilizing convention breeding approaches to increase the amount of a nutrient the plant produces in the seed), various genomic and transgenic approaches (Figure 2).

As shown by Broadley and White (2010), 50\% increase in Ca content of rice is achievable and could bring $\mathrm{Ca}$ intake above the recommended values for 0.3 million people (Broadley and White, 2010). Ca fortification of rice is a potential solution for alleviation of Ca insufficiency in sensitive populations. Recently, Naila et al. (2019) have demonstrated that consumption of $300 \mathrm{~g}$ of cooked (100 g of raw) Ca-fortified rice could provide one-fifth of the daily recommended intake of Ca (Naila et al., 2019). While Ca fortification as such may not be the most appropriate long-term 


\begin{abstract}
Natural Genetic Variation
Improved grain Ca bioavailability (reduction of inhibitors)

Improved Ca storage in the endosperm

Translocation within the plant (transcription factors regulating $\mathrm{Ca}$ homeostasis)

Enhanced inter- and intra-cellular $\mathrm{Ca}$ storage and transport

Efficient Ca uptake from rhizosphere by the roots (reduction and chelation)
\end{abstract}

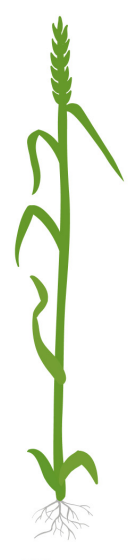

Wheat

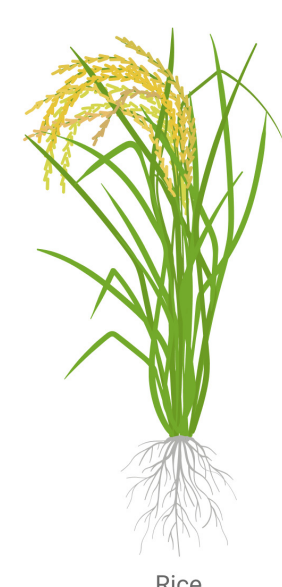

Rice

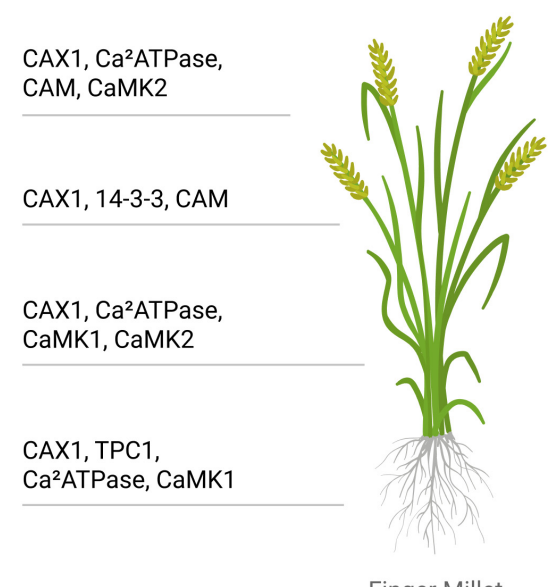

Finger Millet

\section{Conventional Breeding}

Mutants with high Ca content in tissues

Crossing of high Ca varieties to popular varieties/natural variation in

germplasm

\section{Agronomic Approaches}

Plant growth promoting microorganisms
Ca fertilizers
Foliar Ca fertilization

\section{Transgenic Approaches and Emerging Technologies}

Overexpression of $\mathrm{Ca}$ homeostasis related transcription factors

Overexpression of Ca transporters

Overexpression of Ca related genes

Reduction of phytic acid

FIGURE 2 | Potential mechanisms to improve Ca content of major crops. The transporters in finger millet have been studied more extensively, and they are presented lining up to the regions of the plant to where they appear to be expressed; data taken from Mirza et al. (2014) and Puranik et al. (2017).

solution for alleviation of Ca deficiency in developing countries, its benefits certainly emphasize the potential advantages of the enrichment of this major crop with Ca.

Similarly, wheat could be used as a vehicle for improving the $\mathrm{Ca}$ intake of consumers. The average consumption of wheat is $67.5 \mathrm{~kg}$ per person $(\mathrm{FAO} / \mathrm{WHO}, 2002)$, with a significant rise in consumption in Asia (especially China and India) (FAOSTAT, 2017). Wheat lines with high concentrations of $\mathrm{Ca}$ have been identified. When $\mathrm{Ca}$ concentrations were measured in different wheat lines, out of the nine advanced lines of spring breadmaking wheat (Triticum aestivum L.) from the Portuguese Wheat Breeding Program, the highest concentration of $\mathrm{Ca}$ was seen in Nabao and Cultivars 1 and 8, around $480 \mathrm{mg} \mathrm{Ca} / \mathrm{kg}$ (GomezCoronado et al., 2019). Similar concentrations of $\mathrm{Ca}$ in bread wheat plants were found by Calderini and Ortiz-Monasterio (2003), 310-516 mg Ca/kg. Ca concentrations for 150-bread wheat genotypes investigated by Pandey et al. (2016) were around $300 \mathrm{mg} \mathrm{Ca} / \mathrm{kg}$, with a minimum and a maximum value of 106 and 663.5, respectively. Gomez-Becerra et al. (2010) tested 700 lines of spelled wheat grains and reported $\mathrm{Ca}$ concentrations in the range between 132 and $884 \mathrm{mg} \mathrm{Ca} / \mathrm{kg}$. In addition, $40 \%$ lower concentrations of phytic acid were measured in spelled than in wheat flour (Ruibal-Mendieta et al., 2005).
High heritability traits demonstrated for spelled grain show that the new spelled breeding lines with improved concentrations of Ca could be developed (Gomez-Becerra et al., 2010). In the 64-bread wheat and 21-durum wheat varieties commonly grown in Turkey, Ca concentrations varied between 266 and 531 , with a mean value of $378 \mathrm{mg} \mathrm{Ca} / \mathrm{kg}$ in bread wheat, and 215-468 with a mean of $330 \mathrm{mg} \mathrm{Ca} / \mathrm{kg}$ in durum wheat (Harmankaya et al., 2012).

In summary, biofortification of major staple crops is a widely accepted, low-cost strategy that could provide essential nutrients for people. The challenge is now not only to produce Ca-rich staple crops but to make the Ca bioavailable so as to have a beneficial effect on Ca status of consumers.

\section{GENETIC DIVERSITY AND TRANSGENIC APPROACHES}

Genetic marker development (i.e., through the identification of quantitative trait loci (QTL) and underlying genes responsible) is important for studying and manipulating complex traits important to agriculture and for recognizing genetic differences present within the plant species. The approach could 
greatly accelerate genetic modification of $\mathrm{Ca}$ amounts in a number of crops.

Over the years, a number of QTLs for $\mathrm{Ca}$ accumulation in grains of certain crops plants (i.e., wheat, rice, sorghum, barley, maize, and pearl millet) have been identified (Peleg et al., 2009; Zhang et al., 2009; Goel et al., 2011; Fedorowicz-Strońska et al., 2017; Sharma et al., 2017). Ca accumulation in hexaploid wheat grains is controlled by multiple loci, located mainly on chromosomes $2 \mathrm{~A}, 3 \mathrm{~A}, 5 \mathrm{~A}$, and $6 \mathrm{~A}$, one on $5 \mathrm{D}$ and one on the 5B chromosome (Alomari et al., 2017).

Nine significant QTLs were associated with Ca concentrations in wheat grains (Peleg et al., 2009). The genome wide association study of Ca concentrations in bread wheat (Triticum aestivum) was performed on 353 genotypes from a European wheat diversity panel and demonstrated that the most significant gene for $\mathrm{Ca}$ accumulation was located on chromosome $5 \mathrm{~A}$ (Alomari et al., 2017).

Importantly, the heritability was 0.73 across the 2 years, and, while an environmental effect was present, the relatively moderate heritability would allow for genetic gains to be made in a plant breeding context. Ultimately, both genetic and environmental factors have a significant effect on $\mathrm{Ca}$ concentration in wheat and maize grains ( $\mathrm{Gu}$ et al., 2015; Alomari et al., 2017).

Goel et al. (2011) presented a complete genome wide comparative analysis of the $\mathrm{Ca}$ transporter gene family in rice and sorghum. The accumulation of $\mathrm{Ca}$ in rice and sorghum involved 31 and 28 transporter genes, respectively; however, not all of these proteins were involved in Ca accumulation per se (Goel et al., 2011). In rice, the transporters were distributed on nine out of 12 chromosomes, while sorghum transporters could be found on all except on chromosome 10 (Goel et al., 2011). Phylogenetic analysis divided proteins into four clusters: Ca channel, IIA- and IIB-type Ca, ATP-ases, and a Ca exchanger. What was interesting is that $\mathrm{Ca}$ transporters were not evenly distributed but rather clustered on certain chromosomes (Goel et al., 2011). Three QTLs identified in rice plants were mapped in the marker interval STS41t9-RM7 on chromosome 3, RM5271RM216 on chromosome 10, and RM21-RM3428 on chromosome 11 , with $14.3,18.7$, and $13.0 \%$ of the variation in $\mathrm{Ca}$ accumulation (Du et al., 2013). In rice plants, qCa1-1 loci on chromosome 1 accounted for about $9-14 \%$ of phenotypic dissimilarity in $\mathrm{Ca}$ concentrations in rice (Garcia-Oliveira et al., 2009). The genotype had a significant effect on $\mathrm{Ca}$ concentrations. For example, the lowest concentrations of $\mathrm{Ca}$ were measured in the Bacanora T88 wheat line while the concentrations did not differ between the Rayon F89 and a synthetic line (Calderini and OrtizMonasterio, 2003), so synthetic hexaploids may be a useful source for increasing $\mathrm{Ca}$ concentrations of wheat plants.

The genetic diversity of finger millet has been extensively examined in recent years, and a large collection of germplasm has been investigated with 15 accessions identified as most promising for improving Ca content (Upadhyaya et al., 2011, 2014; Shambhavi et al., 2020). About $82 \%$ of the entire genome size of finger millet was assembled, using the modern generation sequencing technologies (Hittalmani et al., 2017). Transport and accumulation of Ca have also been studied across various genotypes, using the high throughput RNA sequencing technology. The low and the high $\mathrm{Ca}$ content finger millet grains had different genotypes, GPHCPB1 and GPHCPB45, respectively (Kumar et al., 2015). The highest concentration of $\mathrm{Ca}$ was measured in GPHCPB44, GPHCPB45, IE6537, and IE2957 accessions (Yadav et al., 2020). EGEP60 and UGEP78 markers accounted for 6.4 and $13.8 \%$ phenotypic variance in finger millet (Yadav et al., 2020).

The exogenous supply of Ca was positively correlated with the expression of Ca sensor genes (Singh et al., 2014). Two Ca-binding proteins were identified in finger millet seeds, calcineurin-B, and calreticulin. Shoots of plants overexpressing calreticulin have higher Ca levels and may be potential targets for genetic manipulation (Broadley and White, 2010).

The mechanism by which $\mathrm{Ca}$ is moved and transported into the seed is not completely understood, but some preliminary data suggest that $\mathrm{Ca}$ transporters are the main $\mathrm{Ca}$-transporting proteins (Li, 2006). CaM-sensor proteins, localized in the embryo close to the aleurone layer, are controlling the activities of most of the Ca transporters. Higher abundance of CaM around the aleurone layer was seen in the seeds of high grain $\mathrm{Ca}$ genotypes, which implies that $\mathrm{CaM}$ may be accountable for the high accumulation of $\mathrm{Ca}$ in the grains.

Candidate genes that could be applied to enrich $\mathrm{Ca}$ concentration have been studied, using Brassica napus genotypes, with the use of an associative transcriptomics approach through an application of the candidate genes selected based on Arabidopsis thaliana-distinguished functions (Alcock et al., 2017).

The leaf $\mathrm{Ca}$ concentration was significantly correlated with loci on chromosomes A10, A3, A6, A, C9, C2, and C3. A10 and $\mathrm{C} 9$ were the most highly associated loci with $\mathrm{Ca}$ content. Flowering locus $\mathrm{C}$ (FLC) and suppressor or overexpression of CO1 (SOC1) markers were associated with $\mathrm{Ca}$ concentrations in leaves (Alcock et al., 2017). The ACA8 gene was shown as a promising candidate for the control of $\mathrm{Ca}$ accumulation in Brassica napus (Alcock et al., 2017). The favorable candidate for influencing the translocation of $\mathrm{Ca}$ to particular tissues in crop plants was the gene that encodes nuclear transport factor 2 (NTF2). In Arabidopsis thaliana, five QTLs with $36.4 \%$ of the variation in Ca content were recognized (Vreugdenhil et al., 2004). The investigation of the magnitude of variability in a core germplasm collection of pearl millet revealed accessions differing in Ca content from 85 to $249 \mathrm{mg} / \mathrm{kg}$ with heritability estimates of over 0.81 (Govindaraj et al., 2020). A strong genetic control was observed for $\mathrm{Ca}$ with a lower magnitude of genotype $\times$ environment relationships (Govindaraj et al., 2020). Very high heritability traits were days to 50\% flowering, $77 \%$ for $\mathrm{Ca}$, and the relative performance of accessions for $\mathrm{Ca}$ did not differ significantly from one season to another, confirming persistent genetic regulation. Flowering was directly correlated with $\mathrm{Ca}$, so late-flowering accessions had a longer time to collect Ca than early flowering counterparts, and small shrunken grains had higher Ca content (Govindaraj et al., 2020).

Breeding studies demonstrated genotypic variability in common bean varieties in the traits responsible for Ca content. Promising common bean populations with high $\mathrm{Ca}$ content have 
been identified, showing that $80 \%$ of the Ca content of common beans is concentrated in the seed coat (Fernandes et al., 2016). A hard-to-cook phenotype in the lpal common bean line was associated with redistribution of $\mathrm{Ca}$ mainly in the cell walls (Cominelli et al., 2020). However, different results were found in various grain tissues; both higher and lower concentrations of $\mathrm{Ca}$ were seen in maize, soybean, and barley between the lpa mutants and the wild type (Bryant et al., 2005; Lin et al., 2005; Landoni et al., 2013).

Development of mapping populations, breeding, and mutant lines would be valuable for grouping the varieties according to the grain Ca content. Genome wide association studies that obtain new genetic information could help in identifying the genes involved in $\mathrm{Ca}$ accumulation in various grains and in identifying the most appropriate varieties for biofortification. The achievement of Ca biofortification of major crops depends on the extent of characterized germplasm for numerous traits that could be offered to breeders for breeding Ca-rich cultivars.

Transgenic approaches to improve the $\mathrm{Ca}$ concentration in plants have also been studied. The Ca content of plants usually increases with a rise in external Ca supply (White, 2001). Ca supply to the plant can be improved by mobilizing soilavailable $\mathrm{Ca}$ or by improving $\mathrm{Ca}$ absorption through a more extensive root system (Puranik et al., 2017). Sequestration of Ca within a plant cell depends on the $\mathrm{Ca}^{2+} / \mathrm{H}^{+}$antiporter (CAX1) situated on the tonoplast. The manipulation of the CAX gene in Arabidopsis produced twofold more Ca compared with control plants, with no alterations in oxalate levels and growth (Hirschi, 2009; Dayod et al., 2010). Similarly, potatoes, carrots, and lettuce with increased $\mathrm{Ca}$ concentration have been produced by an expression of a single copy of the CAX1 gene (Yang et al., 2012). However, the overexpression of the CAX gene promoted $\mathrm{Ca}$ deficiency symptoms in vulnerable tissues (Dayod et al., 2010). The Ca concentration of some plants has been increased with overexpression of tonoplast Ca transporters, i.e., in lettuce, watermelon, and potato tubes (Han et al., 2009; Park et al., 2009). Certain Ca sensors and binding genes [i.e., type IIB ATPase, $\mathrm{Ca}^{2+} / \mathrm{H}^{+}$antiporter (CAX1), calmodulin (CaM), two-pore channel (TPC1), and CaM-dependent protein kinases (CaMK1 and CaMK2)] are proposed as responsible for $\mathrm{Ca}$ enhancement and accumulation within the finger millet grains (Figure 2; Puranik et al., 2017).

Cation/proton exchangers (CAX) transporters are good candidates for increasing bioavailable $\mathrm{Ca}$ in plants, but the expression should be stimulated cautiously to avoid deficiency symptoms that arise in certain tissues. Important to note, simply increasing the Ca supply to cells is not always providing the expected enhancement of $\mathrm{Ca}$ concentration, which clearly means that a leading factor in the process is the Ca transport within the cells.

Modern breeding techniques, i.e., CRISPR/Cas-based tools, offer exciting new opportunities for creating directed genetic diversity. These techniques allow the generation of site-specific genetic diversity and improve the identification of genes underlying certain QTLs (Shan et al., 2013; Yin et al., 2017; Wolter et al., 2019). Furthermore, the procedures enable manipulation of wild relatives of certain crops as a beneficial source of allele mining, open up the genetic diversity from uncultured species, and accelerate the domestication process significantly (Shan et al., 2013; Kumlehn et al., 2018). In addition, CRIPS enables immediate generation of genomic diversity and fine-tuning of desirable traits (Wolter et al., 2019). Finally, novel plant breeding methods could speed up the production of crop plants with desired traits that will meet the challenges related to the food supply, climate change, and environmental sustainability (Ahmar et al., 2020).

In summary, the genetic diversity of $\mathrm{Ca}$ content in various crop varieties has been examined. Certain markers and genome sequences that control Ca content of major crops are already identified, but they remain to be adequately scrutinized. The identification of all the genes that control the accumulation of $\mathrm{Ca}$ into various grains requires an extensive genome-wide examination. Identification of these genes can help in the development of transgenic plants to further aid in understanding Ca transport in plants. Modern plant-breeding approaches should be employed for faster identification and implementation of exact molecular mechanisms for crop improvement.

\section{CONCLUSION AND RECOMMENDATIONS FOR FURTHER RESEARCH}

Calcium is an essential plant nutrient vital for human health. Dietary Ca deficiency remains prevalent among people in developing and developed countries, causing a number of diseases: osteoporosis, inadequate bone mineralization, hypertension, diabetes, and various forms of cancers. At the same time, the demand for staple food crops is increasing and is expected to get higher. More nutrient dense staple food crops could provide a solution to the $\mathrm{Ca}$ malnutrition-related problems. Food fortification and supplementation have not been successful long-term strategies for resolving the inadequacy of intake of many other nutrients, so they probably will not work for Ca either.

On the other hand, the biofortification of main crops could be an effective strategy for increasing $\mathrm{Ca}$ content of crop plants. Breeding staple crops with higher $\mathrm{Ca}$ concentrations is a sustainable long-term strategy for alleviating ensuing $\mathrm{Ca}$ deficiency by providing sufficient amounts of $\mathrm{Ca}$ for populations dependent on plant foods as a basic food source and those with limited and/or restricted access to dairy foods.

Before a Ca biofortification program moves forward, it is important to identify physiological and evolutionary restraints to improving $\mathrm{Ca}$ concentration of edible portions of major crops to define the most suitable crop plants and crop parts for planned interventions. Breeding for increased Ca bioavailability is a perplexing task as bioavailability depends on a number of factors: the genotype, the accumulation of antinutrients, the mineral interactions, the colonization of plants by fungi, the $\mathrm{Ca}$ uptake systems, etc. Similarly, a rapid screening method of $\mathrm{Ca}$ bioavailability could be developed. 
A better understanding of the Ca physiology of plants is needed to design crop breeding strategies that will increase both the Ca concentration of grains and also the yield.

Finger millet, a crop with a higher grain Ca concentration, is a great candidate for learning about mechanisms that contribute to Ca accumulation in grain crops and should be used as an example for increasing the Ca content of other most frequently consumed staple crops. Certain QTLs for Ca accumulation and augmented Ca uptake are already known, but more work is needed in order to completely elucidate loci involved in target crops. Breeding programs for the development of plant crops with the ability to accumulate more $\mathrm{Ca}$ from the soil and translocate it to the edible parts should be pursued. The identification of food preparation methods that could reduce the negative impact of antinutrients, oxalates and phytates, on Ca bioavailability is essential.

Calcium-rich grains have the potential to improve the $\mathrm{Ca}$ status of consumers, especially those with cereal-based dietary patterns and those with limited intake of milk and dairy products. The development of Ca-biofortified cereals requires welldeveloped methodologies for the evaluation of Ca bioaccessibility and appropriate strategies for assessing the efficacy of $\mathrm{Ca}$ biofortified crops in improving the Ca status of consumers. Both in vitro, i.e., caco- 2 cells, and in vivo methods should be developed and employed in order to adequately assess the bioaccessibility of $\mathrm{Ca}$ of projected $\mathrm{Ca}$ biofortified cereal grains. Optimal processing and food preparation practices are the key elements in this process. Procedures, such as fermentation, soaking, processing, and cooking, are all well-known for their inhibitory effect on phytic acid activity in cereals grains. The antinutritional effects of phytate are significantly reduced by these procedures, which lead to improved Ca bioaccessibility. Potential long-term negative effects of reduced phytate levels on human health should be taken into account. Environmental conditions that affect the Ca content of crops should be carefully examined and adequately addressed where possible.

Further research is needed to determine the key drivers of $\mathrm{Ca}$ concentrations in various crops, the link between

\section{REFERENCES}

Abid, M., Jabbar, S., Wu, T., Hashim, M. M., Hu, B., Lei, S., et al. (2014). Sonication enhances polyphenolic compounds, sugars, carotenoids and mineral elements of apple juice. Ultrason. Sonochem. 21, 93-97.

Ahmar, S., Gill, R. A., Jung, K. H., Faheem, A., Qasim, M. U., Mubeen, M., et al. (2020). Conventional and molecular techniques from simple breeding to speed breeding in crop plants: recent advances and future outlook. Int. J. Mol. Sci. 21:2590. doi: 10.3390/ijms21072590

Alcock, T. D., Havlickova, L., He, Z., Bancroft, I., White, P. J., Broadley, M. R., et al. (2017). Identification of candidate genes for calcium and magnesium accumulation in Brassica napus L. by association genetics. Front. Plant Sci. 8:1968. doi: 10.3389/fpls.2017.01968

Alomari, D. Z., Eggert, K., von Wiren, N., Pillen, K., and Roder, M. S. (2017). Genome-wide association study of calcium accumulation in grains of European wheat cultivars. Front. Plant Sci. 8:1797. doi: 10.3389/fpls.2017.01797

Amalraj, A., and Pius, A. (2015). Bioavailability of calcium and its absorption inhibitors in raw and cooked green leafy vegetables commonly consumed in India-an in vitro study. Food Chem. 170, 430-436. doi: 10.1016/j.foodchem. 2014.08.031 the soil and crop characteristics, and, finally, the effect that climate and agricultural practices may have on $\mathrm{Ca}$ accumulation in an assortment of crop plants. Policies that promote and encourage the development and application of Ca-biofortified cereals in developed countries should be part of the general approach to improving dietary intake of $\mathrm{Ca}$ in most vulnerable populations. Finally, in order for Ca-biofortified cereals to be successfully developed, tested, and, finally, adequately implemented in susceptible population groups, research, political will, partnership, investment, collaboration, government engagement, leadership, and constant innovation of applicable methods are needed. A multidisciplinary approach and collaboration among health, food, agriculture, and social protection systems are of crucial importance in this instance.

\section{AUTHOR CONTRIBUTIONS}

MK and JS conceptualized the manuscript. MK wrote the manuscript and prepared the manuscript for submission. JS contributed critically in revising the draft and updating the manuscript for publication. Both authors contributed to the article and approved the submitted version.

\section{FUNDING}

This study was made possible with support from Children's Investment Fund Foundation by means of HarvestPlus. HarvestPlus' principal donors are the United Kingdom Government; the Bill and Melinda Gates Foundation; the United States Government's Feed the Future initiative; Global Affair Canada; the European Commission; and donors to the CGIAR Research Program on Agriculture for Nutrition and Health (A4NH). HarvestPlus is also supported by the John D. and Catherine T. MacArthur Foundation.

Arnaud, J., Pettifor, J. M., Cimma, J. P., Fischer, P. R., Craviari, T., Meisner, C., et al. (2007). Clinical and radiographic improvement of rickets in Bangladeshi children as a result of nutritional advice. Ann. Trop. Paediatr. 27, 185-191. doi: 10.1179/146532807X220299

Asemi, Z., and Esmaillzadeh, A. (2013). Effect of daily consumption of probiotic yoghurt on serum levels of calcium, iron and liver enzymes in pregnant women. Int. J. Prev. Med. 4, 949-955.

Balk, E. M., Adam, G. P., Langberg, V. N., Earley, A., Clark, P., Ebeling, P. R., et al. (2017). Global dietary calcium intake among adults: a systematic review. Osteoporos. Int. 28, 3315-3324. doi: 10.1007/s00198-017-4230-x

Bennett, B. L., and Sammartano, R. (2005). The Complete Idiot's Guide to Vegan Living. Baltimore, MD: Alpha.

Bevis, L. E., and Hestrin, R. (2020). Widespread heterogeneity in staple crop mineral concentration in Uganda partially driven by soil characteristics. Environ. Geochem. Health 43, 1-23. doi: 10.1007/s10653-020-00 698-w

Bouzari, A., Holstege, D., and Barrett, D. M. (2015). Mineral, fiber, and total phenolic retention in eight fruits and vegetables: a comparison of refrigerated and frozen storage. J. Agric. Food Chem. 63, 951-956. doi: 10.1021/jf504 $890 \mathrm{k}$ 
Bowen, D. E., Souza, E. J., Guttieri, M. J., Raboy, V., and Fu, J. (2007). A low phytic acid barley mutation alters seed gene expression. Crop Sci. 47:S-149-S-159. doi: 10.2135/cropsci2006.07.0456tpg

Bressani, R. (1990). Chemistry, technology, and nutritive value of maize tortillas. Food Rev. Int. 6, 225-264. doi: 10.1080/87559129009540868

Broadley, M. R., Bowen, H. C., Cotterill, H. L., Hammond, J. P., Meacham, M. C., Mead, A., et al. (2003). Variation in the shoot calcium content of angiosperms. J. Exp. Bot. 54, 1431-1446. doi: 10.1093/jxb/erg143

Broadley, M. R., and White, P. J. (2010). Eats roots and leaves. Can edible horticultural crops address dietary calcium, magnesium and potassium deficiencies? Proc. Nutr. Soc. 69, 601-612. doi: 10.1017/s0029665110001588

Bromage, S., Ahmed, T., and Fawzi, W. W. (2016). Calcium deficiency in Bangladesh: burden and proposed solutions for the first 1000 days. Food Nutr. Bull. 37, 475-493. doi: 10.1177/0379572116652748

Bryant, R., Dorsch, J., Peterson, K., Rutger, J., and Raboy, V. (2005). Phosphorus and mineral concentrations in whole grain and milled low phytic acid (lpa) 1-1 rice. Cereal Chem. 82, 517-522. doi: 10.1094/cc-82-0517

Calderini, D. F., and Ortiz-Monasterio, I. (2003). Grain position affects grain macronutrient and micronutrient concentrations in wheat. Crop Sci. 43, 141151. doi: $10.2135 /$ cropsci2003.0141

Chan, B. K., Marshall, L. M., Winters, K. M., Faulkner, K. A., Schwartz, A. V., and Orwoll, E. S. (2007). Incident fall risk and physical activity and physical performance among older men: the osteoporotic fractures in men study. Am. J. Epidemiol. 165, 696-703. doi: 10.1093/aje/kwk050

Cichy, K., and Raboy, V. (2009). ). Evaluation and development of low-phytate crops. modification of seed composition to promote health and nutrition. Agron. Monogr. 51, 17-200.

Cominelli, E., Galimberti, M., Pongrac, P., Landoni, M., Losa, A., Paolo, D., et al. (2020). Calcium redistribution contributes to the hard-to-cook phenotype and increases PHA-L lectin thermal stability in common bean low phytic acid 1 mutant seeds. Food Chem. 321:126680. doi: 10.1016/j.foodchem.2020.126680

Conn, S., and Gilliham, M. (2010). Comparative physiology of elemental distributions in plants. Ann. Bot. 105, 1081-1102. doi: 10.1093/aob/mcq027

Dayod, M., Tyerman, S. D., Leigh, R. A., and Gilliham, M. (2010). Calcium storage in plants and the implications for calcium biofortification. Protoplasma 247, 215-231. doi: 10.1007/s00709-010-0182-180

Dewey, K. G. (2016). Reducing stunting by improving maternal, infant and young child nutrition in regions such as South Asia: evidence, challenges and opportunities. Matern. Child. Nutr. 12(Suppl. 1), 27-38. doi: 10.1111/mcn. 12282

Dodd, A. N., Kudla, J., and Sanders, D. (2010). The language of calcium signaling. Ann. Rev. Plant Biol. 61, 593-620. doi: 10.1146/annurev-arplant-070109104628

Dragicevic, V., Kratovalieva, S., Dimov, Z., Babic, V., Kresovic, B., and Kravic, N. (2018). Potential bioavailability of calcium, magnesium, iron, manganese and zinc from seeds of different chickpea and peanut landraces. J. Elem. 23, 273-285. doi: 10.5601/jelem.2016.21.4.1377

Du, J., Zeng, D., Wang, B., Qian, Q., Zheng, S., and Ling, H.-Q. (2013). Environmental effects on mineral accumulation in rice grains and identification of ecological specific QTLs. Environ. Geochem. Health 35, 161-170. doi: 10. 1007/s10653-012-9473-z

Ekbote, V. H., Khadilkar, A. V., Khadilkar, V. V., Chiplonkar, S. A., and Mughal, Z. (2017). Dietary patterns with special reference to calcium intake in 2-16year-old Urban Western Indian children. Indian J. Public Health 61:188. doi: 10.4103/ijph.ijph_85_16

Eller, F., and Brix, H. (2015). Influence of low calcium availability on cadmium uptake and translocation in a fast-growing shrub and a metal-accumulating herb. AoB Plants 8:lv143. doi: 10.1093/aobpla/plv143

Fairweather-Tait, S., and Hurrell, R. F. (2007). Bioavailability of minerals and trace elements: members of EC flair concerted action No. 10: measurements of micronutrient absorption and status. Nutr. Res. Rev. 9, 295-324. doi: 10.1079/ NRR19960016

FAO in India, UNICEF, WFP, and WHO (2020). Brief to the State of Food Security and Nutrition in the World 2020. Rome: FAO.

FAO/WHO (2002). Human Vitamin and Mineral Requirements, Report of a Joint FAO/WHO Expert Consultation. Rome: FAO.

FAOSTAT (2017). Food and Agriculture Commodities Production. Rome: FAOSTAT.
Fedorowicz-Strońska, O., Koczyk, G., Kaczmarek, M., Krajewski, P., and Sadowski, J. (2017). Genome-wide identification, characterisation and expression profiles of calcium-dependent protein kinase genes in barley (Hordeum vulgare L.). J. Appl. Genet. 58, 11-22. doi: 10.1007/s13353-016-0357-2

Feng, X., Zhang, H., and Yu, P. (2020). X-ray fluorescence application in food, feed, and agricultural science: a critical review. Crit. Rev. Food Sci. Nutr. doi: 10.1080/10408398.2020.1776677 Online ahead of print.

Fernandes, S. B., Abreu, A. F., and Ramalho, M. A. (2016). Genotype x environment interaction and its implication in identification of common bean populations with high calcium content. Genet. Mol. Res. 15, doi: 10.4238/gmr.15028053

Ficco, D. B. M., Riefolo, C., Nicastro, G., De Simone, V., Di Gesù, A. M., Beleggia, R., et al. (2009). Phytate and mineral elements concentration in a collection of Italian durum wheat cultivars. Field Crops Res. 111, 235-242. doi: 10.1016/j.fcr. 2008.12.010

Fleming, K. H., and Heimbach, J. T. (1994). Consumption of calcium in the U.S.: food sources and intake levels. J. Nutr. 124(8 Suppl.), 1426s-1430s. doi: 10.1093/ jn/124.suppl_8.1426S

Fordyce, F. (2005). Essentials of Medical Geology, Impacts of the Natural Environment on Public Health. Cambridge, MA: Elsevier.

Fritz, E. (2007). Measurement of cation exchange capacity (CEC) of plant cell walls by X-ray microanalysis (EDX) in the transmission electron microscope. Microscopy Microanal. 13, 233-244. doi: 10.1017/s143192760707 0420

Gao, X., LaValley, M. P., and Tucker, K. L. (2005). Prospective studies of dairy product and calcium intakes and prostate cancer risk: a meta-analysis. J. Natl. Cancer Ins. 97, 1768-1777. doi: 10.1093/jnci/dji402

Garcia-Oliveira, A. L., Tan, L., Fu, Y., and Sun, C. (2009). Genetic identification of quantitative trait loci for contents of mineral nutrients in rice grain. J. Integr. Plant Biol. 51, 84-92. doi: 10.1111/j.1744-7909.2008.00730.x

Gibson, R. S., Bailey, K. B., Gibbs, M., and Ferguson, E. L. (2010). A review of phytate, iron, zinc, and calcium concentrations in plant-based complementary foods used in low-income countries and implications for bioavailability. Food Nutr. Bull. 31 (2 Suppl.), S134-S146.

Goel, A., Taj, G., Pandey, D., Gupta, S., and Kumar, A. (2011). Genome-wide comparative in silico analysis of calcium transporters of rice and sorghum. GPB 9, 138-150. doi: 10.1016/s1672-0229(11)60017-x

Gomez-Becerra, H. F., Erdem, H., Yazici, A., Tutus, Y., Torun, B., Ozturk, L., et al. (2010). Grain concentrations of protein and mineral nutrients in a large collection of spelt wheat grown under different environments. J. Cer. Sci. 52, 342-349. doi: 10.1016/j.jcs.2010.05.003

Gomez-Coronado, F., Almeida, A. S., Santamaria, O., Cakmak, I., and Poblaciones, M. J. (2019). Potential of advanced breeding lines of bread-making wheat to accumulate grain minerals $(\mathrm{Ca}, \mathrm{Fe}, \mathrm{Mg}$ and $\mathrm{Zn}$ ) and low phytates under mediterranean conditions. J. Agron. Crop. Sci. 205, 341-352. doi: 10.1111/jac. 12325

Gonçalves, B., Borges, O., Rosa, E., Coutinho, J., and Silva, A. P. (2012). Effect of cooking on free amino acid and mineral profiles of sweet chestnut (Castanea sativa Mill.). Fruits 67, 201-214. doi: 10.1051/fruits/2012013

Gong, X., Liu, Y., Huang, D., Zeng, G., Liu, S., Tang, H., et al. (2016). Effects of exogenous calcium and spermidine on cadmium stress moderation and metal accumulation in Boehmeria nivea (L.) Gaudich. Environ. Sci. Pollut. Res. 23, 8699-8708. doi: 10.1007/s11356-016-6122-6126

Govindaraj, M., Rai, K. N., Kanatti, A., Upadhyaya, H. D., Shivade, H., and Rao, A. S. (2020). Exploring the genetic variability and diversity of pearl millet core collection germplasm for grain nutritional traits improvement. Sci. Rep. 10:21177. doi: 10.1038/s41598-020-77818-77810

Graham, R., and Welch, R. (1995). Breeding for staple-food crops with high micronutrient density. J. Expert. Bot. 55, 353-364.

Graham, R. D., Welch, R. M., Saunders, D. A., Ortiz-Monasterio, I., Bouis, H. E., Bonierbale, M., et al. (2007). "Nutritious subsistence food systems," in $A d v$. Agron, ed. D. L. Sparks (Cambridge, MA: Academic Press), 1-74. doi: 10.1016/ s0065-2113(04)92001-9

Gu, R., Chen, F., Liu, B., Wang, X., Liu, J., Li, P., et al. (2015). Comprehensive phenotypic analysis and quantitative trait locus identification for grain mineral concentration, content, and yield in maize (Zea mays L.). Theor. Appl. Genet. 128, 1777-1789. doi: 10.1007/s00122-015-2546-5

Guild, G. E., Paltridge, N. G., Andersson, M. S., and Stangoulis, J. C. R. (2017). An energy-dispersive X-ray fluorescence method for analysing $\mathrm{Fe}$ and $\mathrm{Zn}$ in 
common bean, maize and cowpea biofortification programs. Plant Soil 419, 457-466. doi: 10.1007/s11104-017-3352-3354

Guo, L., Bafang, L., Hu, H., Paìdraigiìn, A. H., Richard, J. F., Xue, Z., et al. (2014). Food protein-derived chelating peptides: biofunctional ingredients for dietary mineral bioavailability enhancement. Trends Food Sci. Technol. 37, 92-105. doi: 10.1016/j.tifs.2014.02.007

Haldipur, V. (2003). Boning Up on Osteoporosis. Available online at: http: //timesofindia.indiatimes.com/bombay-times/Boning-up-on-osteoporosis/ articleshow/329075.cms (accessed January 13, 2021).

Hallberg, L., Rossander-Hulten, L., Brune, M., and Gleerup, A. (1992). Calcium and iron absorption: mechanism of action and nutritional importance. Europ. J. Clin. Nutr. 46, 317-327.

Han, J.-S., Park, S., Shigaki, T., Hirschi, K. D., and Kim, C. K. (2009). Improved watermelon quality using bottle gourd rootstock expressing a $\mathrm{Ca} 2+/ \mathrm{H}+$ antiporter. Mol. Breed. 24, 201-211. doi: 10.1007/s11032-009-9284-9

Harmankaya, M., Özcan, M. M., and Gezgin, S. (2012). Variation of heavy metal and micro and macro element concentrations of bread and durum wheats and their relationship in grain of Turkish wheat cultivars. Environ. Monit. Assess 184, 5511-5521. doi: 10.1007/s10661-011-2357-3

Heaney, R. P., and Weaver, C. M. (1989). Oxalate: effect on calcium absorbability. Am. J. Clin. Nutr. 50, 830-832. doi: 10.1093/ajcn/50.4.830

Heaney, R. P., Weaver, C. M., and Fitzsimmons, M. L. (1991). Soybean phytate content: effect on calcium absorption. Am. J. Clin. Nutr. 53, 745-747. doi: 10.1093/ajcn/53.3.745

Heaney, R. P., Weaver, C. M., and Recker, R. R. (1989). Calcium absorbability from spinach. Am. J. Clin. Nutr. 47, 707-709. doi: 10.1093/ajcn/47.4.707

Hefnawy, T. (2011). Effect of processing methods on nutritional composition and anti-nutritional factors in lentils (Lens culinaris). Ann. Agric. Sci. 56, 57-61. doi: 10.1016/j.aoas.2011.07.001

Hemanalini, G., Umapathy, K. P., Rao, J. R., and Saraswathi, G. (1980). Nutritional evaluation of sprouted ragi. Nutr. Rep. Int. 22, 271-277.

Hirschi, K. D. (2009). Nutrient biofortification of food crops. Ann. Rev. Nutr. 29, 401-421. doi: 10.1146/annurev-nutr-080508-141143

Hittalmani, S., Mahesh, H., Shirke, M. D., Biradar, H., Uday, G., Aruna, Y., et al. (2017). Genome and transcriptome sequence of finger millet (Eleusine coracana (L.) Gaertn.) provides insights into drought tolerance and nutraceutical properties. BMC Gen. 18:465. doi: 10.1186/s12864-017-3850-z

Ho, L. C., and White, P. J. (2005). A cellular hypothesis for the induction of blossom-end rot in tomato fruit. Ann. Bot. 95, 571-581. doi: 10.1093/aob/ mci065

Huang, D., Gong, X., Liu, Y., Zeng, G., Lai, C., Bashir, H., et al. (2017). Effects of calcium at toxic concentrations of cadmium in plants. Planta 245, 863-873. doi: 10.1007/s00425-017-2664-2661

Jefferies, R. L., and Willis, A. J. (1964). Studies on the calcicole-calcifuge habit: I. methods of analysis of soil and plant tissues and some results of investigations on four species. J. Ecol. 52, 121-138. doi: 10.2307/2257787

Jeong, J., and Guerinot, M. L. (2008). Biofortified and bioavailable: the gold standard for plant-based diets. Proc. Natl. Acad. Sci. U S A. 105, 1777-1778. doi: 10.1073/pnas.0712330105

Joy, E. J., Broadley, M. R., Young, S. D., Black, C. R., Chilimba, A. D., Ander, E. L., et al. (2015). Soil type influences crop mineral composition in Malawi. Sci. Total Environ. 505, 587-595. doi: 10.1016/j.scitotenv.2014.10.038

Juliano, B. (1990). Rice grain quality: problems and challenges. Cereal Food World $35,245-253$.

Kalcsits, L. A. (2016). Non-destructive measurement of calcium and potassium in apple and pear using handheld X-ray fluorescence. Front. Plant Sci. 7:442. doi: $10.3389 /$ fpls.2016.00442

Kamchan, A., Puwastien, P., Sirichakwal, P. P., and Kongkachuichai, R. (2004). In vitro calcium bioavailability of vegetables, legumes and seeds. J. Food Comp. Anal. 17, 311-320. doi: 10.1016/j.jfca.2004.03.002

Karley, A. J., Leigh, R. A., and Sanders, D. (2000). Differential ion accumulation and ion fluxes in the mesophyll and epidermis of barley. Plant Physiol. 122, 835-844. doi: 10.1104/pp.122.3.835

Karley, A. J., and White, P. J. (2009). Moving cationic minerals to edible tissues: potassium, magnesium, calcium. Curr. Opin. Plant Biol. 12, 291-298. doi: 10. 1016/j.pbi.2009.04.013

Kranz, S., Lin, P.-J., and Wagstaff, D. A. (2007). Children's dairy intake in the United States: too little, too fat? J. Pediatr. 151:642-6, 646.e1-2
Krishnan, R., Dharmaraj, U., and Malleshi, N. G. (2012). Influence of decortication, popping and malting on bioaccessibility of calcium, iron and zinc in finger millet. LWT-Food Sci. Technol. 48, 169-174. doi: 10.1016/j.lwt.2012.03.003

Kumar, A., Gaur, V. S., Goel, A., and Gupta, A. K. (2015). De novo assembly and characterization of developing spikes transcriptome of finger millet (Eleusine coracana): a minor crop having nutraceutical properties. Plant Mol. Boil. Rep. 33, 905-922. doi: 10.1007/s11105-014-0802-5

Kumar, A., Metwal, M., Kaur, S., Gupta, A. K., Puranik, S., Singh, S., et al. (2016). Nutraceutical value of finger millet [Eleusine coracana (L.) Gaertn.], and their improvement using omics approaches. Front. Plant Sci. 7:934. doi: 10.3389/fpls. 2016.00934

Kumlehn, J., Pietralla, J., Hensel, G., Pacher, M., and Puchta, H. (2018). The CRISPR/Cas revolution continues: from efficient gene editing for crop breeding to plant synthetic biology. J. Integr. Plant Biol. 60, 1127-1153. doi: 10.1111/jipb. 12734

Kumssa, D. B., Joy, E. J. M., Ander, E. L., Watts, M. J., Young, S. D., Walker, S., et al. (2015). Dietary calcium and zinc deficiency risks are decreasing but remain prevalent. Sci. Rep. 5:10974.

Landoni, M., Cerino Badone, F., Haman, N., Schiraldi, A., Fessas, D., Cesari, V., et al. (2013). Low phytic acid 1 mutation in maize modifies density, starch properties, cations, and fiber contents in the seed. J. Agric. Food. Chem. 61, 4622-4630. doi: 10.1021/jf400259h

Lanham-New, S. A. (2006). Fruit and Vegetables: the Unexpected Natural Answer to the Question of Osteoporosis Prevention?. Oxford: Oxford University Press.

Leigh, R. A., and Sanders, D. (1997). The Plant Vacuole (Advances in Botanical Research). London: Academic Press.

Li, X. (2006). The Importance of Sorting Calcium in Plant Cells: Uncovering the Roles of a Sarcoplasmic/Endoplasmic Reticulum-Like Calcium ATPase. PhD thesis, College Park, MD: University of Maryland.

Lin, J., Manson, J. E., Lee, I.-M., Cook, N. R., Buring, J. E., and Zhang, S. M. (2007). Intakes of calcium and vitamin $\mathrm{D}$ and breast cancer risk in women. Arch. Intern. Med. 167, 1050-1059. doi: 10.1001/archinte.167.10.1050

Lin, L., Ockenden, I., and Lott, J. N. (2005). The concentrations and distribution of phytic acid-phosphorus and other mineral nutrients in wild-type and low phytic acid 1-1 (lpa 1-1) corn (Zea mays L.) grains and grain parts. Can. J. Bot. 83, 131-141. doi: 10.1139/b04-146

Lindsay, R., Silverman, S. L., Cooper, C., Hanley, D. A., Barton, I., Broy, S. B., et al. (2001). Risk of new vertebral fracture in the year following a fracture. JAMA 285, 320-323. doi: 10.1001/jama.285.3.320

Lott, J., Bojarski, M., Kolasa, J., Batten, G., and Campbell, L. (2009). A review of the phosphorus content of dry cereal and legume crops of the world. Int. J. Agric. Resour. Gov. Ecol. 8, 351-370. doi: 10.1504/IJARGE.2009.032640

Lucarini, M., Canali, R., Cappelloni, M., Di Lullo, G., and Lombardi-Boccia, G. (1999). In vitro calcium availability from brassica vegetables (Brassica oleracea L.) and as consumed in composite dishes. Food Chem. 64, 519-523. doi: 10. 1016/s0308-8146(98)00159-9

Lynch, S. R. (2000). The effect of calcium on iron absorption. Nutr. Res. Rev. 13, 141-158. doi: 10.1079/095442200108729043

Ma, S., Churkina, G., Gessler, A., Wieland, R., and Bellocchi, G. (2016). Yield gap of winter wheat in Europe and sensitivity of potential yield to climate factors. Clim. Res. 67, 179-190. doi: 10.3354/cr01367

Makokha, A. O., Oniang'o, R. K., Njoroge, S. M., and Kamar, O. K. (2002). Effect of traditional fermentation and malting on phytic acid and mineral availability from sorghum (Sorghum bicolor) and finger millet (Eleusine coracana) grain varieties grown in Kenya. Food Nutr. Bull. 23, 241-245. doi: $10.1177 / 15648265020233 s 147$

Martínez-Ballesta, M. C., Dominguez-Perles, R., Moreno, D. A., Muries, B., Alcaraz-López, C., Bastías, E., et al. (2010). Minerals in plant food: effect of agricultural practices and role in human health. a review. Agron. Sustain. Dev. 30, 295-309. doi: 10.1051/agro/2009022

Mbithi-Mwikya, S., Van Camp, J., Yiru, Y., and Huyghebaert, A. (2000). Nutrient and antinutrient changes in finger millet (Eleusine coracan) during sprouting. LWT-Food Sci. Technol. 33, 9-14. doi: 10.1006/fstl.1999. 0605

McCance, R., and Widdowson, E. M. (1942). Mineral metabolism of healthy adults on white and brown bread dietaries. J. Physiol. 101:44. doi: 10.1113/jphysiol. 1942.sp003967 
McCarron, D. A. (1989). Calcium metabolism and hypertension. Kidney Int. 35, 717-736. doi: 10.1038/ki.1989.44

McCarthy, W. P., Daly, K., Fenelon, A., O'Connor, C., McCarthy, N. A., Hogan, S. A., et al. (2020). Energy-dispersive X-ray fluorescence spectrometry as a tool for the rapid determination of the five major minerals $(\mathrm{Na}, \mathrm{Mg}, \mathrm{K}, \mathrm{P}$ and $\mathrm{Ca}$ ) in skim milk powder. Int. J. Dairy Technol. 73, 459-467. doi: 10.1111/1471-0307. 12677

McKevith, B. (2004). Nutritional aspects of cereals. Nutr. Bull. 29, 111-142. doi: 10.1111/j.1467-3010.2004.00418.x

McLaughlin, S. B., and Wimmer, R. (1999). Calcium physiology and terrestrial ecosystem processes. New Phytol. 142, 373-417. doi: 10.1046/j.1469-8137.1999. 00420.x

Mirza, N., Taj, G., Arora, S., and Kumar, A. (2014). Transcriptional expression analysis of genes involved in regulation of calcium translocation and storage in finger millet [Eleusine coracana (L.) Gartn.]. Gene 550, 171-179. doi: 10.1016/j. gene.2014.08.005

Mohiyuddin, S. S., Reddy, S. R., Kumai, L. A., and Doss, P. J. (2010). Acephate induced alterations in $\mathrm{Mg}^{2+}$-ATPase and $\mathrm{Na}^{+} / \mathrm{K}^{+}$-ATPase of different brain regions of albino rats. Bioscan 5, 153-156.

Morris, E. R., and Ellis, R. (1989). Usefulness of the dietary phytic acid/ zinc molar ratio as an index of zinc bioavailability to rats and humans. Bio. Trace Elem. Res. 19, 107-117. doi: 10.1007/BF02925452

Morris, J., Hawthorne, K. M., Hotze, T., Abrams, S. A., and Hirschi, K. D. (2008). Nutritional impact of elevated calcium transport activity in carrots. Proc. Natl. Acad. Sci. U S A. 105, 1431-1435. doi: 10.1073/pnas.0709005105

Morris, J., Nakata, P. A., McConn, M., Brock, A., and Hirschi, K. D. (2007). Increased calcium bioavailability in mice fed genetically engineered plants lacking calcium oxalate. Plant Mol. Biol. 64, 613-618. doi: 10.1007/s11103-0079180-9189

Naila, N. N., Mondal, P., Bromage, S., Islam, M. M., Huda, M. M., Shomik, M. S., et al. (2019). Home Fortification of rice with lime: a novel potential way to reduce calcium deficiency in Bangladesh. Food Nutr. Bull. 40, 357-368. doi: $10.1177 / 0379572119845573$

Nordin, B. (1997). Calcium in health and disease. Food Nutr. Agri. 20, 13-26.

Ocheme, O., Oludamilola, O. O., and Gladys, M. E. (2010). Effect of lime soaking and cooking (nixtamalization) on the proximate, functional and some antinutritional properties of millet flour. AU J. Technol. 14, 131-138.

Oli, P., Ward, R., Adhikari, B., Mawson, A. J., Adhikari, R., Wess, T., et al. (2016). Synchrotron X-ray fluorescence microscopy study of the diffusion of iron, manganese, potassium and zinc in parboiled rice kernels. LWT-Food Sci. Technol. 71, 138-148. doi: 10.1016/j.lwt.2016.03.034

Palacios-Fonseca, A. J., Vazquez-Ramos, C., and Rodríguez-García, M. E. (2009). Physicochemical characterizing of industrial and traditional nixtamalized corn flours. J. Food Eng. 93, 45-51. doi: 10.1016/j.jfoodeng.2008.12.030

Pandey, A., Khan, M. K., Hakki, E. E., et al. (2016). Assessment of genetic variability for grain nutrients from diverse regions: potential for wheat improvement. Springer Plus 5:1912.

Parikh, S. J., and Yanovski, J. A. (2003). Calcium intake and adiposity. Am. J. Clin. Nutr. 77, 281-287. doi: 10.1093/ajcn/77.2.281

Park, S., Elless, M. P., Park, J., Jenkins, A., Lim, W., Chambers, et al. (2009). Sensory analysis of calcium-biofortified lettuce. Plant Biotechnol. J. 7, 106-117. doi: $10.1111 /$ j.1467-7652.2008.00379.x

Parvaneh, K., Ebrahimi, M., Sabran, M. R., Karimi, G., Hwei, A. N., AbdulMajeed, S., et al. (2015). Probiotics (Bifidobacterium longum) increase bone mass density and upregulate sparc and Bmp-2 genes in rats with bone loss resulting from ovariectomy. BioMed. Res. Int. 2015:897639. doi: 10.1155/2015/ 897639

Peleg, Z., Cakmak, I., Ozturk, L., Yazici, A., Jun, Y., Budak, H., et al. (2009). Quantitative trait loci conferring grain mineral nutrient concentrations in durum wheat $\times$ wild emmer wheat RIL population. Theor. Appl. Genet. 119, 353-369. doi: 10.1007/s00122-009-1044-z

Pettifor, J. M., Thandrayen, K., and Thacher, T. D. (2018). Vitamin D Deficiency and Nutritional Rickets in Children. Amsterdam: Elsevier.

Platel, K., Eipeson, S. W., and Srinivasan, K. (2010). Bioaccessible mineral content of malted finger millet (Eleusine coracana), wheat (Triticum aestivum), and barley (Hordeum vulgare). J. Agric. Food Chem. 58, 8100-8103. doi: 10.1021/ jf100846e
Prasad, R., and Shivay, Y. S. (2020). Agronomic biofortification of plant foods with minerals, vitamins and metabolites with chemical fertilizers and liming. J. Plant Nutr. 43, 1534-1554. doi: 10.1080/01904167.2020.1738464

Pravina, P., Sayaji, D., and Avinash, M. (2013). Calcium and its role in human body. Int. J. Res. Pharm. Biomed. Sci. 4, 659-668.

Puranik, S., Kam, J., Sahu, P. P., Yadav, R., Srivastava, R. K., Ojulong, H., et al. (2017). Harnessing finger millet to combat calcium deficiency in humans: challenges and prospects. Front. Plant Sci. 8:1311. doi: 10.3389/fpls.2017. 01311

Raboy, V. (2020). Low phytic acid crops: observations based on four decades of research. Plants (Basel) 9:140. doi: 10.3390/plants9020140

Roldan-Cruz, C., Garcia-Diaz, S., Garcia-Hernandez, A., Alvarez-Ramirez, J., and Vernon-Carter, E. J. (2020). Microstructural changes and in vitro digestibility of maize starch treated with different calcium compounds used in nixtamalization processes. Starch - Stärke 72:1900303. doi: 10.1002/star.20190 0303

Rosado, J. L., Díaz, M., Rosas, A., Griffit, I., and García, O. P. (2005). Calcium absorption from corn tortilla is relatively high and is dependent upon calcium content and liming in Mexican women. J. Nutr. 135, 2578-2581. doi: 10.1093/ jn/135.11.2578

Ruibal-Mendieta, N. L., Delacroix, D. L., Mignolet, E., Pycke, J. M., Marques, C., Rozenberg, R., et al. (2005). Spelt (Triticum aestivum ssp. spelta) as a source of breadmaking flours and bran naturally enriched in oleic acid and minerals but not phytic acid. J. Agric. Food Chem. 53. 2751-2759. doi: 10.1021/jf048 506 e

Saleh, A. S., Zhang, Q., Chen, J. and Shen, Q. (2013). Millet Grains: nutritional quality, processing, and potential health benefits. Comp. Rev. Food Sci. Food Safety 12, 281-295. doi: 10.1111/1541-4337.12012

Sanwalka, N. J., Khadilkar, A. V., and Chiplonkar, S. A. (2011). Development of non-dairy, calcium-rich vegetarian food products to improve calcium intake in vegetarian youth. Curr. Sci. 101, 657-663.

Savage, G. P., Vanhanen, L., Mason, S. M., and Ross, A. B. (2000). Effect of cooking on the soluble and insoluble oxalate content of some new zealand foods. J. Food Compost. Anal. 13, 201-206. doi: 10.1006/jfca.2000.0879

Scholz-Ahrens, K. E. (2016). "Prebiotics, probiotics, synbiotics and foods with regard to bone metabolism," in Nutritional Influences on Bone Health, eds C. M. Weaver, R. M. Daly, and H. A. Bischoff-Ferrari (Cham: Springer), 153-167.

Seetharam, A. (2001). Annual Report 2000-01. Bangalore: All India Coordinated Small Millets Improvement Project, 1-28.

Shambhavi, Y., Anil, K., and Salej, S. (2020). Unraveling the genetics of calcium content in finger millet grains through association mapping. Indian J. Genet. $80,432-440$.

Shan, Q., Wang, Y., Li, J., Zhang, Y., Chen, K., Liang, Z., et al. (2013). Targeted genome modification of crop plants using a CRISPR-Cas system. Nature Biotech. 31, 686-688. doi: 10.1038/nbt.2650

Sharma, A., Jood, S., and Sehgal, S. (1996). Antinutrients (phytic acid, polyphenols) and minerals $(\mathrm{Ca}, \mathrm{Fe})$ availability (in vitro) of chickpea and lentil cultivars. Nahrung 40, 182-184. doi: 10.1002/food.19960400404

Sharma, D., Jamra, G., Singh, U. M., Sood, S., and Kumar, A. (2017). Calcium biofortification: three pronged molecular approaches for dissecting complex trait of calcium nutrition in finger millet (Eleusine coracana) for devising strategies of enrichment of food crops. Front. Plant Sci. 7:2028. doi: 10.3389/ fpls.2016.02028

Shobana, S., Krishnaswamy, K., Sudha, V., Malleshi, N. G., Anjana, R. M., Palaniappan, L., et al. (2013). Finger millet (Ragi, Eleusine coracana L.): a review of its nutritional properties, processing, and plausible health benefits. Adv. Food Nutr. Res. 69, 1-39. doi: 10.1016/B978-0-12-410540-9.00 001-6

Singh, B. R., McLaughlin, M. J., and Brevik, E. C. (eds). (2017). The Nexus of Soils, Plants, Animals and Human Health Catena-Schweizerbart, Stuttgart.

Singh, P., and Raghuvanshi, R. S. (2012). Finger millet for food and nutritional security. Afr. J. Food Sci. 6, 77-84.

Singh, U. M., Pandey, D., and Kumar, A. (2014). Determination of calcium responsiveness towards exogenous application in two genotypes of Eleusine coracana L. differing in their grain calcium content. Acta Physiol. Plant 36, 2521-2529. doi: 10.1007/s11738-014-1625-6 
Skibsted, L. H. (2016). Mineral nutrient interaction: improving bioavailability of calcium and iron. Food Sci. Biotechnol. 25, 1233-1241. doi: 10.1007/s10068016-0196-192

The Food and Agriculture Organization (FAO) United Nations (2002). Human Vitamin and Mineral Requirements, Report of A Joint FAO/WHO Expert Consultation [Online]. Rome: FAO. Available online at: ftp://ftp.fao.org/docrep/ fao/004/y2809e/y2809e00.pdf.2020.

Thompson, B. A. V., Sharp, P. A., Elliott, R., and Fairweather-Tait, S. J. (2010). Inhibitory effect of calcium on non-heme iron absorption may be related to trans location of DMT-1 at the apical membrane of enterocytes. J. Agric. Food Chem. 58, 8414-8417. doi: 10.1021/jf101388z

Toklu, F., Ozkan, H., Karaköy, T., and Coyne, C. J. (2017). Evaluation of advanced lentil lines for diversity in seed mineral concentration, grain yield and yield components. Tarim Bilim. Dergisi 23, 213-222.

Torres, J., Domínguez, S., Cerdá, M. F., Obal, G., Mederos, A., Irvine, R. F., et al. (2005). Solution behaviour of myo-inositol hexakisphosphate in the presence of multivalent cations. Prediction of a neutral pentamagnesium species under cytosolic/nuclear conditions. J. Inorg. Biochem. 99, 828-840. doi: 10.1016/j. jinorgbio.2004.12.011

Upadhyaya, H., Dwivedi, S., Sharma, S., Lalitha, N., Singh, S., Varshney, R., et al. (2014). Enhancement of the use and impact of germplasm in crop improvement. Plant Genet. Resour. 12, S155-S159.

Upadhyaya, H. D., Ramesh, S., Sharma, S., Singh, S., Varshney, S., Sarma, N., et al. (2011). Genetic diversity for grain nutrients contents in a core collection of finger millet (Eleusine coracana (L.) Gaertn.) germplasm. Field Crops Res. 121, 42-52. doi: 10.1016/j.fcr.2010.11.017

Vatanparast, H., Bailey, D. A., Baxter-Jones, A. D., and Whiting, S. J. (2010). Calcium requirements for bone growth in Canadian boys and girls during adolescence. Br. J. Nutr. 103, 575-580. doi: 10.1017/s000711450999 2522

Velu, G., Ortiz-Monasterio, I., Cakmak, I., Hao, Y., and Singh, R. Á (2014). Biofortification strategies to increase grain zinc and iron concentrations in wheat. J. Cereal Sci. 59, 365-372. doi: 10.1016/j.jcs.2013. 09.001

Vigani, G., Bohic, S., Faoro, F., Vekemans, B., Vincze, L., and Terzano, R. (2018). Cellular fractionation and nanoscopic X-ray fluorescence imaging analyses reveal changes of zinc distribution in leaf cells of iron-deficient plants. Front. Plant Sci. 9:1112. doi: 10.3389/fpls.2018.01112

Vinco Pimenta, A., Agrizzi Verediano, T., Souza Carneiro, J. C., Brunoro Costa, N. M., and Vasconcelos Costa, A. G. (2020). Bioaccessibility and bioavailability of calcium in sprouted brown and golden flaxseed. J. Sci. Food Agric. 101, 2788-2798. doi: 10.1002/jsfa.10908

Vinoth, A., and Ravindhran, R. (2017). Biofortification in millets: a sustainable approach for nutritional security. Front. Plant Sci. 8:29. doi: 10.3389/fpls.2017. 00029

Vreugdenhil, D., Aarts, M., Koornneef, M., Nelissen, H., and Ernst, W. (2004). Natural variation and QTL analysis for cationic mineral content in seeds of Arabidopsis thaliana. Plant Cell Environ. 27, 828-839. doi: 10.1111/j.1365-3040. 2004.01189.x

Weaver, C. M., Heaney, R. P., Proulx, W. R., Hinders, S. M., and Packard, P. T. (1993). Absorbability of calcium from common beans. J. Food Sci. 58, 14011403.

Weaver, C. M., Proulx, W. R., and Heaney, R. (1999). Choices for achieving adequate dietary calcium with a vegetarian diet. Am. J. Clin. Nutr. 70, 543s548s. doi: $10.1093 / \mathrm{ajcn} / 70.3 .543 \mathrm{~s}$
Welch, A. A., Fransen, H., Jenab, M., Boutron-Ruault, M. C., Tumino, R., Agnoli, C., et al. (2009). Variation in intakes of calcium, phosphorus, magnesium, iron and potassium in 10 countries in the European Prospective Investigation into Cancer and Nutrition study. Eur. J. Clin. Nutr. 63, S101-S121. doi: 10.1038/ejcn. 2009.77

Welch, R. M., and Graham, R. D. (1999). A new paradigm for world agriculture: meeting human needs: productive, sustainable, nutritious. Field Crop. Res. 60, 1-10. doi: 10.1016/s0378-4290(98)00129-4

White, P. J. (2001). The pathways of calcium movement to the xylem. J. Exp. Bot. 52, 891-899. doi: 10.1093/jexbot/52.358.891

White, P. J., and Broadley, M. R. (2003). Calcium in plants. Ann. Bot. 92, 487-511. doi: $10.1093 / \mathrm{aob} / \mathrm{mcg} 164$

White, P. J., and Broadley, M. R. (2005). Biofortifying crops with essential mineral elements. Trends Plant Sci. 10, 586-593. doi: 10.1016/j.tplants.2005.10.001

Wolter, F., Schindele, P., and Puchta, H. (2019). Plant breeding at the speed of light: the power of CRISPR/Cas to generate directed genetic diversity at multiple sites. BMC Plant Biol. 19:176. doi: 10.1186/s12870-019-1775-1

Wood, S. A., Tirfessa, D., and Baudron, F. (2018). Soil organic matter underlies crop nutritional quality and productivity in smallholder agriculture. Agric. Ecosyst. Environ. 266, 100-108. doi: 10.1016/j.agee.2018.07.025

Yadav, S., Kumar, A., and Sood, S. (2020). Unraveling the genetics of calcium content in finger millet grains through association mapping. Indian J. Genet. 80, 432-440. doi: 10.31742/IJGPB.80.4.9

Yang, J., Punshon, T., Guerinot, M. L., and Hirschi, K. D. (2012). Plant calcium content: ready to remodel. Nutrients 4, 1120-1136. doi: 10.3390/nu4081120

Yin, K., Gao, C., and Qiu, J. L. (2017). Progress and prospects in plant genome editing. Nat. Plants 3:17107.

Zhang, B., Chen, P., Shi, A., Hou, A., Ishibashi, T., and Wang, D. (2009). Putative quantitative trait loci associated with calcium content in soybean seed. J. Hered. 100, 263-269. doi: 10.1093/jhered/esn096

Zhang, S., Li, Q., Nazir, M. M., Ali, S., Ouyang, Y. N., Ye, S. Z., et al. (2020a). Calcium plays a double-edged role in modulating cadmium uptake and translocation in rice. Int. J. Mol. Sci. 21:8058. doi: 10.3390/ijms21218058

Zhang, Y. Y., Stockmann, R., Ng, K., and Ajlouni, S. (2020b). Opportunities for plant-derived enhancers for iron, zinc, and calcium bioavailability: a review. Compr. Rev. Food Sci. Food Saf. 20, 652-685. doi: 10.1111/1541-4337.12669

Zhang, Y. Y., Stockmann, R., Ng, K., and Ajlouni, S. (2020c). Revisiting phytateelement interactions: implications for iron, zinc and calcium bioavailability, with emphasis on legumes. Crit. Rev. Food Sci. Nutr. 16, 1-17. doi: 10.1080/ 10408398.2020.1846014

Zhang, T., Sun, H., Lv, Z., Cui, L., Mao, H., and Kopittke, P. M. (2017). Using synchrotron-based approaches to examine the foliar application of $\mathrm{ZnSO} 4$ and $\mathrm{ZnO}$ nanoparticles for field-grown winter wheat. J. Agric. Food Chem. 66, 2572-2579. doi: 10.1021/acs.jafc.7b04153

Conflict of Interest: The authors declare that the research was conducted in the absence of any commercial or financial relationships that could be construed as a potential conflict of interest.

Copyright (C) 2021 Knez and Stangoulis. This is an open-access article distributed under the terms of the Creative Commons Attribution License (CC BY). The use, distribution or reproduction in other forums is permitted, provided the original author(s) and the copyright owner(s) are credited and that the original publication in this journal is cited, in accordance with accepted academic practice. No use, distribution or reproduction is permitted which does not comply with these terms. 